\title{
Corrosion of Ultrafine Grained Materials by Severe Plastic Deformation, an Overview
}

\author{
Hiroyuki Miyamoto* \\ Department of Mechanical Engineering, Doshisha University, Kyotanabe 610-0394, Japan
}

Corrosion of ultrafine grain (UFG) materials by severe plastic deformation (SPD) is reviewed in light of the existing literature and microstructural change. Fortunately, by holistic survey of the literature, it seems likely that grain refinement by SPD, while enhancing mechanical properties, does not compromise the overall corrosion resistance, and in many case, improve it in comparison with coarse-grained counterparts, although there are some contradictory results within the same materials and same environment. The degree of impact of UFG formation on corrosion is highest in stainless steels followed by aluminum and magnesium alloys whereas it is relatively marginal in pure copper and titanium. The effect of UFG formation by SPD on corrosion is imparted by not only grain refinement, but also other microstructural change occurring commonly in SPD in general and unique to each specific SPD method. In this review, an attention is paid specifically to the former case, and this includes shuffling or redistribution of chemical inhomogeneity into a finer scale, deformation-induced grain boundaries and high internal stress stemming from these grain boundaries. The literature on stress corrosion cracking (SCC) of UFG materials are definitely insufficient to find the general trends, more studies are waited. [doi:10.2320/matertrans.M2015452]

(Received December 7, 2015; Accepted February 29, 2016; Published April 8, 2016)

Keywords: $\quad$ ultrafine grain materials, severe plastic deformation, corrosion

\section{Introduction}

Grain refinement of metallic materials to sub-micron or nano-scale by severe plastic deformation (SPD) has been well-recognized by the community of materials scientists. The advent of SPD have broken the wall of the minimum grain size achievable by the conventional thermomechanical processing, and realized the fabrication of materials with the so-called ultrafine grain (UFG) structure in a bulk form for load-carrying structural components. A vast number of papers on microstructures, mechanical, and other physical properties of ultrafine grained (UFG) or nanostructured materials by SPD represented by equal-channel angular pressing (ECAP), high-pressure torsion (HPT), and accumulative roll bonding (ARB) has been published for more than past two decades. Several comprehensive review papers on the principle of SPD processing and properties of UFG materials by SPD were published. ${ }^{1-5)}$ The obvious advantage of SPD is to fabricate UFG materials in a bulk form of varying scales with no specific requirement of alloy elements, and applicable to a wide range of materials from pure metals to multi-phase materials except for very hard and brittle materials. This is especially important for biomaterials application where biocompatibility restricts applicable chemical compositions. ${ }^{6-8)}$

UFG structures by SPD are mostly composed of deformation-induced grain boundaries, and these grain boundaries are regarded as none-equilibrium boundaries. ${ }^{9-11)}$ In deformation-induced grain boundaries, external grain boundary dislocation, or alternatively called extrinsic grain boundary dislocation, are comprised in grain boundaries lending grain boundaries energy higher than those at equilibrium state. This is evidenced by internal dislocations near the grain boundaries observed by transmission electron microscopy (TEM). ${ }^{12-15)}$ Indeed, several unique phenomena were reported, which seems to be attributed to high fraction of non-equilibrium grain boundaries, such as ultra-fast diffusion, ${ }^{16-21)}$

*Corresponding author, E-mail: hmiyamot@mail.doshisha.ac.jp room temperature grain boundary sliding in aluminum. ${ }^{22)}$ Strength and ductility are primary characteristics dependent on the microstructure of a material, and spectacular achievement of braking the trade-off between two has been reported in SPD-UFG materials. ${ }^{23-26)}$ Superplasticity, ${ }^{27)}$ creep, $^{28)}$ viscous deformation, ${ }^{29,30)}$ fatigue strength $^{31,32)}$ are also important "secondary" properties, which are more or less impacted by deformation-induced UFG structures.

Another property of great interest for structural materials is corrosion resistance. Corrosion in polycrystalline materials is affected by grain size, and one would expect to understand the corrosion behavior of UFG materials based primarily on grain size dependency, which is hopefully expressed by HallPetch type universal law. ${ }^{33)}$ This is really challenging task, and has been tried with a wide range of grain size that is systematically changed. ${ }^{33-52)}$ Di Schino et al. ${ }^{41-43)}$ investigated the effect of grain size on corrosion of several austenitic stainless steels, claiming that the rate of uniform corrosion increase by grain size reduction whereas the rate of intergranular corrosion is opposite. Table 1 lists the selected papers which investigated effect of grain size that spans for conventional range controlled by thermomechanical processing. Generally speaking, the rate of corrosion in a local mode such as pitting, intergranular corrosions decrease with decreasing grain size whereas it is opposite in general corrosion. Ralston $^{44)}$ reviewed the literature and clarified the general trends for grain size effect on corrosion by classifying them into three modes of corrosion with regards to dynamic polarization curves; (i) active, (ii) passive, (iii) active/passive types of corrosions. In the active type, corrosion currents are accelerated in finer grain size while an opposite trends are found in the passive type (Fig. 1). ${ }^{44)}$ In the active/passive type, corrosion current show the mixed pattern of the previous two types, namely it is higher in the active region and lower in the passive region. Question arise if these trends hold for submicron- or nano-scale grain size. Corrosion resistance of nanocrystalline metals was first reported by Rofagha et al. on nanocrystalline nickel ${ }^{53)}$ and Ni-P ${ }^{54)}$ synthesized by elec- 
Table 1 Effect of grain size reduction on corrosion.

\begin{tabular}{|c|c|c|c|c|c|}
\hline Materials & Grain size $(\mu \mathrm{m})$ & Corrosion & Mode of Corrosion & Solution & Ref \\
\hline $\mathrm{Al}(99.9999 \%)$ & $120-1600$ & Better & $\mathrm{PD}$ & $0.1 \mathrm{M} \mathrm{NaCl}$ & 35) \\
\hline $\mathrm{Al}$ & $120-1600$ & Better & PD & - & 33) \\
\hline AA6063 & $2.4-2500$ & Worse & PD & $1 \mathrm{M} \mathrm{HCl}$ & 33) \\
\hline High N SS & $2.5-40$ & Worse & GC & boil. $5 \% \mathrm{H}_{2} \mathrm{SO}_{4}$ & 41) \\
\hline High N SS & $2.5-40$ & Better & IGC & Streicher & 41) \\
\hline Low Ni SS & $2.5-50$ & Worse & $\mathrm{GC}$ & boil. $5 \% \mathrm{H}_{2} \mathrm{SO}_{4}$ & 42) \\
\hline Low Ni SS & $2.5-50$ & Better & IGC & Streicher & 42) \\
\hline AISI304 & $1.1-50$ & Worse & $\mathrm{GC}$ & boil. $5 \% \mathrm{H}_{2} \mathrm{SO}_{4}$ & 43) \\
\hline AISI304 & $1.1-50$ & Better & IGC & Streicher & 43) \\
\hline AISI304 & $1.1-50$ & Better & Pitting & $10 \% \mathrm{FeCl}_{3}$ & 43) \\
\hline AISI304 & $1.1-50$ & Better & Pitting & $3.5 \% \mathrm{NaCl}$ & 43) \\
\hline $316 \mathrm{~L}$ & $46-220$ & Worse & $\mathrm{IGC}(\mathrm{PD})$ & 1.0 $\mathrm{M} \mathrm{H}_{2} \mathrm{SO}_{4}+0.003 \mathrm{MNa}_{2} \mathrm{~S}_{4} \mathrm{O}_{6}$ & 215) \\
\hline
\end{tabular}

Better $=$ Corrosion resistance increases with grain size reduction, Worse $=$ Vise versa.

$\mathrm{PD}=$ Potentio-dynamic test, $\mathrm{GC}=\mathrm{General}$ corrosion, $\mathrm{IGC}=$ Intergranular corrosion .
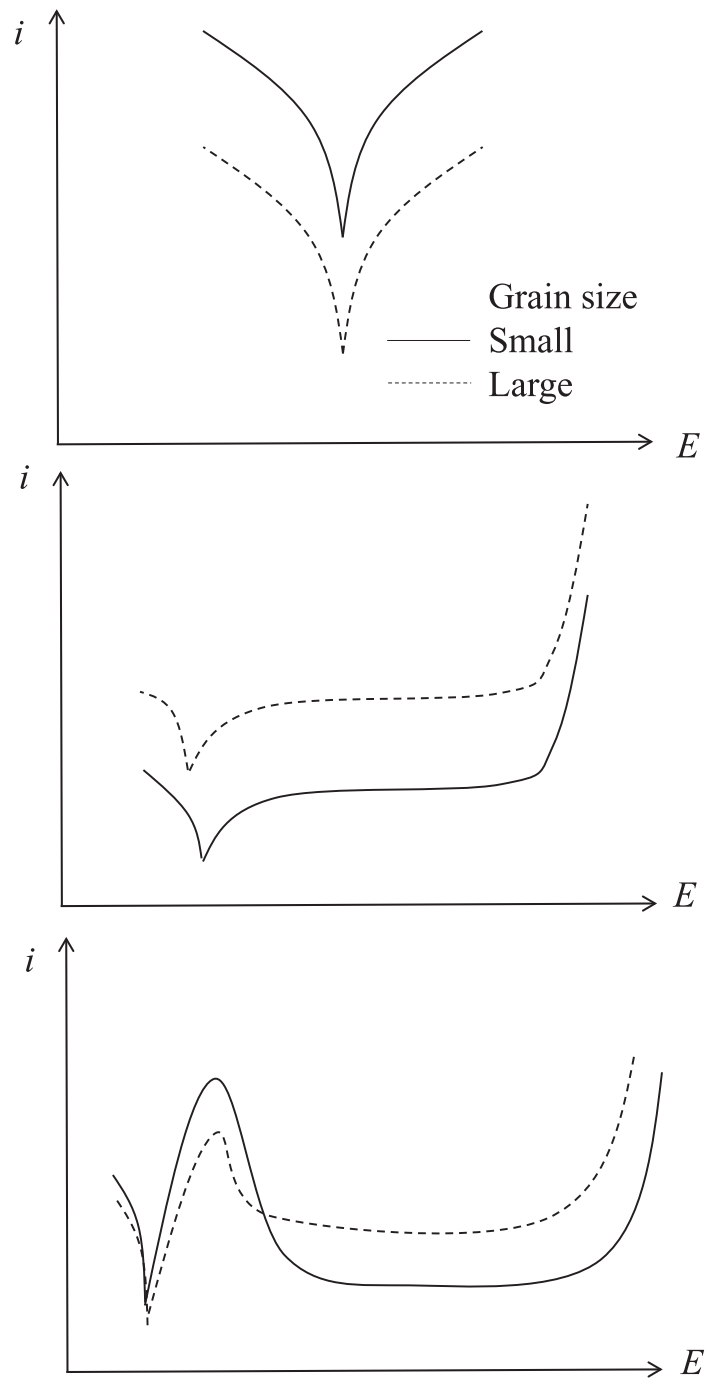

Fig. 1 Effect of grain size on polarization behavior of (a) active, (b) passive and (c) active/passive reactions. Reconstructed with some modification from the figure by Ralston. ${ }^{44}$ trodeposition. According to them, coarse-grained $\mathrm{Ni}$ and Ni-P exhibit passivation behavior while little passivation behavior was observed for the nanocryatalline counterparts, and this result does not follow Ralston's rule. Gupta and Birbilis's review $^{55)}$ on corrosion of nanocrystalline stainless steel fabricated by various methods such as magnetron sputtering, sandblasting, high-energy ball milling, etc supports Ralston's rule, reporting that the resistance to corrosion, especially pitting is improved through higher passivation ability. Koch ${ }^{56)}$ concluded that, as a general trend, in severe corrosive environments in low $\mathrm{pH}$, nanocrytalline metals show lower corrosion resistance whereas in the passive state, pitting or selective corrosion tend to be suppressed. Similarly, nanocrystalline Co exhibit higher corrosion resistance in the passive state in $\mathrm{NaOH}$ solution whereas lower in the active state in $\mathrm{HCl}$ solutions. ${ }^{57)}$

Grain refinement by SPD processing accompanies other microstructural changes in a complicated way. These change includes phase transformation, ${ }^{58,59)}$ redistribution of impurity and solute elements, ${ }^{60,61)}$ the morphology change of precipitation by partial dissolution and physical fragmentation, ${ }^{62-65)}$ residual dislocation density, ${ }^{66,67)}$ texture, ${ }^{68-71)}$ etc. Effect of these changes is superimposed on grain size effect on corrosion, and this may cloud the underlying law dominating grain-size-dependency, if any, generic to SPD.

In this paper, the corrosion properties of UFG materials fabricated by SPD are reviewed by a holistic examination of the existing literature, for presenting a possible rationale of corrosion behavior of UFG materials, based primarily on grain size dependency, but other metallurgical and structural changes occurring commonly during SPD are taken into account. Most of UFG materials in the list are pressed by ECAP, HPT, ARB as the core of SPD technology, but the recent emerging SPD for surface modification such as surface mechanical attrition treatment (SMAT), ${ }^{21,72-74)}$ cryorolling, ${ }^{75,76)}$ high-power shotblast, ${ }^{77-81)}$ burnishing, ${ }^{82-84)}$ friction stir processing (FSP) ${ }^{85,86)}$ are included. However, nanocrystalline metals, which are fabricated by the so-called bottom-up approaches such as magnetron and DC spattering, powder consolidation by high-energy ball milling are excluded in this 
review because these approach impart significant change in other metallurgical parameters which influence corrosion behavior.

\section{Microstructural Change during SPD}

\subsection{Types of UFG materials processed by SPD}

In addition to grain refinement, SPD processing modifies the microstructures in a complicated manner involving phase transformation, distribution of impurity and solute elements, segregation, the morphology of precipitation, dislocation density, texture, etc. Some of them are generic to SPD regardless of processing and some are specific to processing among SPD technology and deformation routes. In reviewing the existing literature on corrosion of UFG materials by SPD, microstructural changes are modeled and classified simply into four types according to the selected metallurgical variables as shown in Fig. 2. These four typified changes are supposed to occur commonly during SPD in general regardless of specific SPD procedures and deformation routes. Although they might occur concurrently in most alloy systems, they are classified by one according to the major microstructural change focused in the papers.

\subsection{Pure metals with high and commercial purity (Type} A)

As the most simple structure, a various kind of pure metals of high and commercial purity such as aluminum, ${ }^{87-94)}$ copper, ${ }^{6,37,95-106)}$ iron, ${ }^{76,107)}$ titanium, ${ }^{108-114)}$ magnesium, ${ }^{34,72,115-117)}$ have been processed by SPD for corrosion studies. In this simple system, grain size or grain boundary density impacts the corrosion resistance as a primary metallurgical variable with very few other metallurgical changes involved. Thus, hopefully, grain size dependency tends to appear and follow a simple law. In general, the minimum grain size achieved by SPD is somewhat larger than its aluminum alloy. ${ }^{18)}$ In many polycrystalline materials, grain boundaries are preferentially attacked during corrosion because of (i) their enhanced energy compared to the perfect crystal, (ii) the less perfect atomic structure, and (iii) their susceptibility to segregation of impurities. ${ }^{119)}$ On the other hand, however, it may promote the formation of passive film and suppress the dissolution in the passive state because the grain boundaries become the nucleation site of passivation film. ${ }^{33)}$ Higher charge-transfer resistance of passive film are interpreted as higher stability of passivation in UFG materials using electron impedance spectroscopy (EIS) in aluminum. ${ }^{88,90,92,120,121)}$ copper, ${ }^{95)}$ magnesium, ${ }^{83,122,123)}$ steel, ${ }^{76,107)}$ stainless steels, ${ }^{73,124)}$ Mechanical adhesion of oxide film can be stronger in UFG materials than in coarse-grain materials by, for example, pegging mechanism. ${ }^{106)}$ Purity of the metals also may influence the effect of grain size on corrosion properties because it affects the degree of impurity atoms residing at grain boundaries. During SPD these segregated atoms may be shuffled and redistributed, and hopefully diluted with increasing volume fraction of grain boundaries, ${ }^{125)}$ although this is not necessarily true. ${ }^{60,61)}$

\subsection{Solid solutions under solution limit (Type B)}

Second class of materials is solid solutions such as $\mathrm{Fe}-\mathrm{Cr}$, $\mathrm{Cu}-\mathrm{Zn}, \mathrm{Al}-\mathrm{Mg}, \mathrm{Al}-\mathrm{Cu}, \mathrm{Mg}-\mathrm{Al}$ system with solute elements under the solution limit. Thermodynamically, some solute elements enhance the dissolution potential of the matrix such as $\mathrm{Cr}$ in $\mathrm{Fe}, \mathrm{Mn}$ and $\mathrm{Cu}$ in $\mathrm{Al}$ and $\mathrm{Al}$ in $\mathrm{Mg}$, or drop it such as $\mathrm{Fe}$ and $\mathrm{Zn}$ in $\mathrm{Al}$, etc. Even in a complete solid solution, solute atoms may stay with some inhomogeneity due to an interaction with heterogeneous structure of crystal defects such as dislocations, grain boundaries, surface, etc, to reduce total free energy. Inhomogeneous distribution of these solute atoms may cause galvanic cells between the regions of high and low concentration, and degrade corrosion performance. The surface concentration of some solute elements often differs from inner bulk in some solid-solution, and the degree of it depends on grain size. If these are passivation former such as

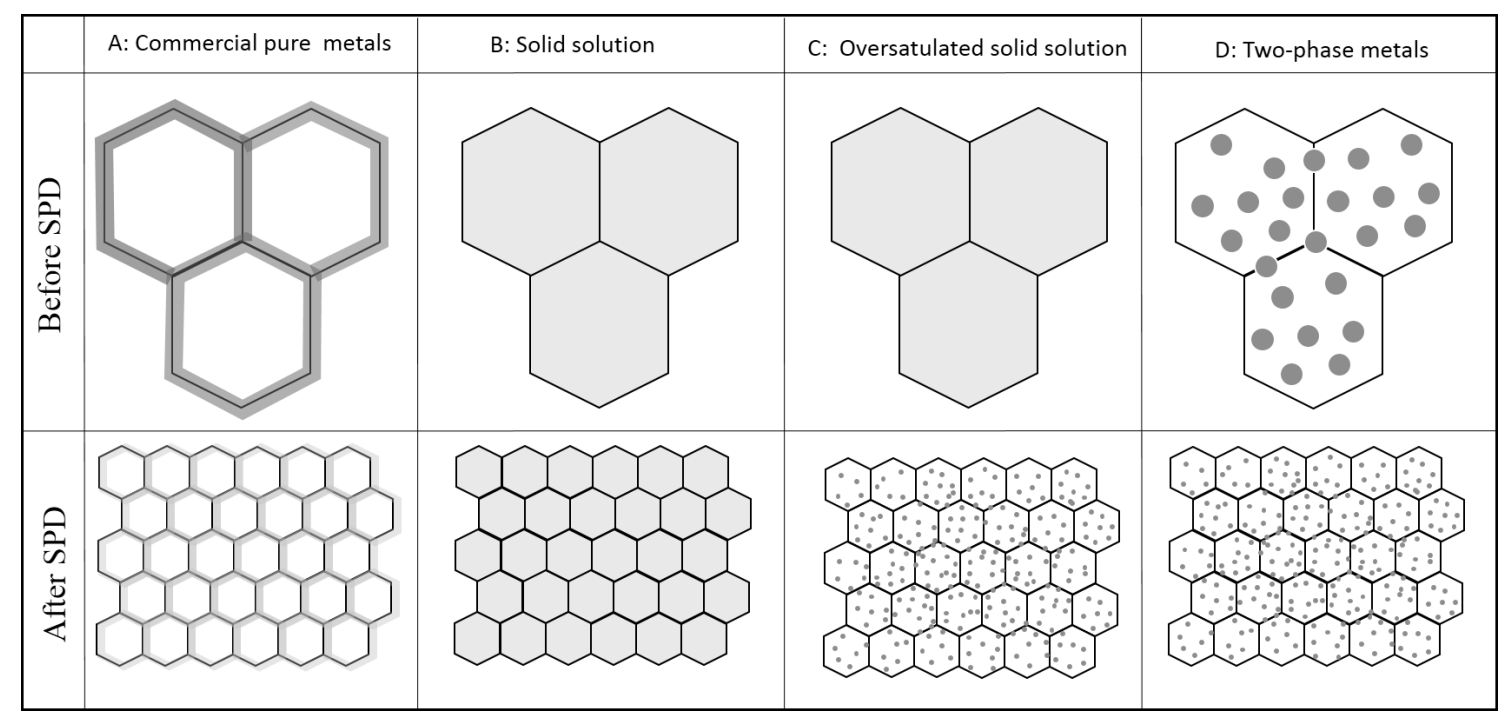

Fig. 2 Four typical microstructural changes during SPD. A; Pure metals of high purity or commercial purity with impurity segregation according to its purity, B: Solid solution with solute elements under the solution limit at room temperature, C: Solid solution with solute elements over solution limit. It is supersaturated prior to SPD, the precipitation may occur during SPD, or post-SPD annealing, D: Two-phase or multi-phase materials, whose second phase may be fragmented physically, or dissolved partially or completely. 
$\mathrm{Cr}$ in $\mathrm{Fe}$ and $\mathrm{Al}$ in $\mathrm{Mg}$, then the degree of inhomogeneity impact corrosion resistance. It was reported that $\mathrm{Cr}$ concentration at the surface was higher in UFG Fe-Cr alloy than that in coarse grain counterparts as evidenced by secondary ion mass spectrometry (SIMS) or X-ray photoelectron spectroscopy (XPS), ${ }^{126-131)}$ and this Cr enrichment of at the surface may result in the higher passivity and resistance to pitting corrosion. ${ }^{126-130)}$ In corrosive media, selective dissolution of solute elements or solvent may also cause concentration gradient near the surface, ${ }^{126,132,133)}$ and UFG structures may promote this tendency, resulting in higher corrosion resistance. $^{126)}$

\subsection{Solid solutions over solution limit (Type C)}

The supersaturated alloy systems with solute elements over solution limit were also processed by SPD in mostly $\mathrm{Al},{ }^{134-138)}$ $\mathrm{Mg},{ }^{139,140)}$ and $\mathrm{Cu}$ alloys. ${ }^{141-144)}$ In this class of materials, the billets were annealed by solution treatment prior to SPD, and subsequently subjected to aging during SPD, or in the postSPD final aging treatment. The temperature of SPD impacts the precipitation kinetics and resultant morphology such as shape, density and size of precipitates. When dissolution potential of the second phase and the matrix is different, the morphology of precipitation may impact corrosion behavior. No phase transformation occur in the aluminum alloys during their processing at cryogenic temperatures due to suppressed diffusion. ${ }^{1,144)}$ However, complex phase transformation take place during SPD at room and elevated temperatures such as nucleation of second phase precipitates, their growth, fragmentation, or dissolution. ${ }^{1)}$ High density of grain boundaries of equilibrium or non-equilibrium structures, along with dislocations and high density of vacancy result in increased diffusion coefficient and accelerated precipitation kinetic. ${ }^{145-149)}$ According to Sha et al., ${ }^{148)}$ evolution of second phase precipitates during ECAP processing of AA7136 at $200^{\circ} \mathrm{C}$ was found to be 50 times faster than during conventional aging treatments of coarse grained counter materials at the same temperature. It was also reported that the precipitation evolution bypass the metastable stage of strengthening phase, and proceeds directly in the growth stage. ${ }^{148,149)}$ Thus, in some processing of aluminum alloys, SPD and aging treatments degrade the mechanical properties. Nevertheless, strengthening by both the grain refinement and precipitation can be compatible in UFG aluminum alloy by elaborate designing for alloys and processing as evidenced by further hardening by precipitation during the post-SPD aging treatment in UFG structure. ${ }^{137,144)}$ Achieving it for magnesium alloy is technically more difficult and challenging, and to the best of my knowledge, its successful result is still waited. With decreasing diffusion path between grain boundaries, solute-depleted zone which inevitably accompany intergranular precipitation in conventional grain size can be eliminated or alleviated. Indeed, $\mathrm{Cu}$-depleted zone in the vicinity of grain boundaries become much smaller ${ }^{87)}$ or disappeared in UFG Al-Cu alloys, ${ }^{150)}$ and this may lead to higher resistance to intergranular corrosion of $\mathrm{Cu}-\mathrm{Al}$ alloy systems. ${ }^{75,150)}$ In passivated materials such as aluminum alloy, the passive film may be different in its stability ${ }^{151)}$ or even absent ${ }^{152)}$ on second phase. Therefore, the distribution of the precipitation strongly affect the resistance to pitting corrosion, and in some cases, its im- pact is stronger than grain size.

\subsection{Two-phase, multi-phase materials (Type D)}

Processing materials with second phase such as eutectic $\mathrm{Al}-\mathrm{Si},{ }^{151,153)}$ and two-phase $(\alpha+\beta) \mathrm{AZ91},{ }^{154)}(\alpha+\beta) \mathrm{Ti}-13 \mathrm{Nb}-$ $13 \mathrm{Zr}$ alloy ${ }^{155)}$ by SPD may impact the corrosion behavior because the dissolution potential between the two phases are generally different such as high-potential $\mathrm{Al}$ rich $\beta$-phase in AZ91 and Si-phase in Al. Most of commercially pure aluminum have also impurity precipitation, and can be regarded as this type. Aged materials with fine precipitation have also been processed by SPD, and in this case, structural change is very complicated. Mechanical fragmentation of the dispersions and precipitation during SPD was demonstrated, which results in finer size. ${ }^{62-65)}$ Dissolution of the second phase into the matrix were also reported in $\mathrm{Al}$ alloys ${ }^{64,156)}$ and $\mathrm{Mg}$ alloy. ${ }^{157)}$ These dissolved elements may precipitate again after SPD, thus Type C and D may occur concurrently and is hard to be clearly separated. When the second phase is nobler than the matrix by large potential difference as in the case of $\mathrm{Al}_{2} \mathrm{Cu}$ intermetallics in aluminum and $\mathrm{Al}_{3} \mathrm{Fe}$ in magnesium alloys, the change of size and distribution of the second phase may impact on the corrosion behavior or stability of passivity. Indeed, fine fragmentation of $\mathrm{Al}_{2} \mathrm{Cu}, \mathrm{FeAl}$ in aluminum alloys ${ }^{87,120,158)}$ and Al-Si alloy ${ }^{151)}$ raise passivity breakdown potential.

\section{Corrosion of UFG Materials by SPD}

\subsection{General description}

Corrosion behavior has been investigated on UFG materials fabricated mainly by processing of SPD such as ECAP, ARB, HPT for aluminum and its alloy, ${ }^{87-93,120,121,143,150-153,156,158-171)}$ magnesium and its alloy, ${ }^{34,72,115-117,122,123,154,157,172-179)}$ copper and its alloy, ${ }^{6,96-99,101,102,105,180)}$ stainless steels, ${ }^{124,181,182)}$ iron and steel, ${ }^{107,183)}$ titanium and its alloys. ${ }^{108-110,112,127,155,184-186)}$ Recently, other SPD processing emerged such as hydraulic extrusion (HE), ${ }^{111)}$ severe- or cryo-cold rolling. ${ }^{45,75,76)}$ These SPD processing generates UFG metals in bulk form, but in other processing, UFG or nanocrytallization can be achieved in the surface layer using high power shot blast, ${ }^{78)}$ ultrasonic peening, ${ }^{77,79,80)}$ surface mechanical attrition treatment (SMAT), ${ }^{72-74)}$ burnishing/brushing ${ }^{82-84)}$ and friction stir processing (FSP). ${ }^{85,86)}$ Table 2 lists the papers reporting on the corrosion behavior of UFG materials by specifically SPD. Materials are divided into four types (Type A to D) according to the microstructural change described in the previous section. Although the actual metallurgical features are more complicated, this classification is simplified extracting the most influential metallurgical variables on corrosion. For example, in many age-hardenable aluminum alloys, type B, C and $\mathrm{D}$ may occur concurrently. The table is meant to provide a general overlook for embossing the common trend, if any, for the impact of UFG formation, and by no means were intended or capable of conveying many detailed conditions and results within the literature. In addition to these microstructural changes accompanied by UFG formation, there are also another ones such as dislocation density, phase transformation, residual stress and texture. Some of these factors are dis- 
Table 2 Summary of corrosion experiments of UFG materials by SPD.

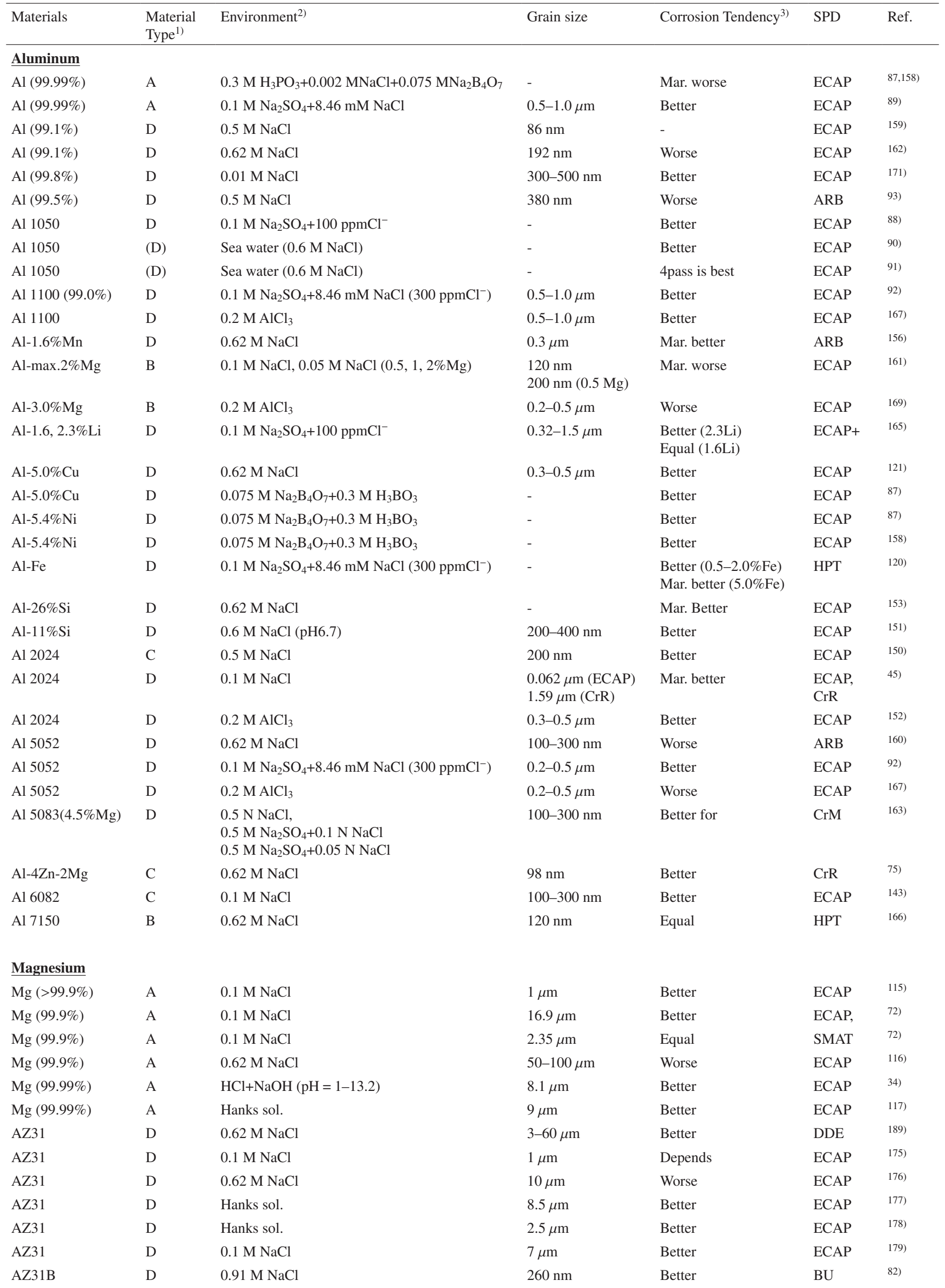




$\begin{array}{lll}\text { AZ31B } & \text { D } & 0.91 \mathrm{M} \mathrm{NaCl} \\ \text { AZ61 } & \text { D } & 0.1 \mathrm{M} \mathrm{NaCl} \\ \text { AZ91D } & \text { D } & 0.62 \mathrm{M} \mathrm{NaCl} \\ \text { AZ91D } & \text { D } & 0.62 \mathrm{M} \mathrm{NaCl} \\ \text { ZE41A } & \text { D } & \text { Hanks sol. } \\ \text { ZE41A } & \text { D } & 0.6-2.5 \mathrm{M} \mathrm{NaCl} \\ & & \\ \text { ZK60 } & \text { D } & 0.1,3.5 \mathrm{M} \mathrm{NaCl} \\ \text { AE42 } & \text { D } & 0.1 \mathrm{M} \mathrm{NaCl} \\ \text { AE21 } & \text { D } & 0.1 \mathrm{M} \mathrm{NaCl} \\ \text { AE42 } & \text { D } & 0.1 \mathrm{M} \mathrm{NaCl} \\ \text { Mg-Zn-Ca } & \text { D } & \text { Hank's } \\ \text { Mg-Y-Nd } & \text { B } & 0.62 \mathrm{M} \mathrm{NaCl}\end{array}$

$$
\begin{aligned}
& 523 \mathrm{~nm} \\
& 1.1-1.5 \mu \mathrm{m} \\
& 1-2 \mu \mathrm{m} \\
& 8-11 \mathrm{~nm} \\
& 2.5 \mu \mathrm{m} \\
& 2.5 \mu \mathrm{m} \\
& 4.2 \mu \mathrm{m} \\
& 3-4 \mu \mathrm{m} \\
& 2-3 \mu \mathrm{m} \\
& 2-3 \mu \mathrm{m} \\
& 1.2 \mu \mathrm{m} \\
& 0.7-70 \mu \mathrm{m}
\end{aligned}
$$

$80-200 \mathrm{~nm}$
$200 \mathrm{~nm}$
$300 \mathrm{~nm}$
$380 \mathrm{~nm}$
$300 \mathrm{~nm}$
$200-300 \mathrm{~nm}$
$200 \mathrm{~nm}$
$200 \mathrm{~nm}$
-
$21 \mathrm{~nm}$

\section{Cupper}

$\mathrm{Cu}(99.96 \%)$

$\mathrm{Cu}(99.95 \%)$

$\mathrm{Cu}(99.99 \%)$

$\mathrm{Cu}(99.97 \%)$

$\mathrm{Cu}(99.96 \%)$

CP (99.95\%)

$\mathrm{Cu}(99.96 \%)$

$\mathrm{Cu}(99.96 \%)$

$\mathrm{Cu}(99.96 \%)$

$\mathrm{Cu}-10 \mathrm{Ni}$

\section{$\underline{\text { Stainless Steels }}$}

\section{$\mathrm{Fe}-20 \% \mathrm{Cr}$}

$\mathrm{Fe}-10,20 \% \mathrm{Cr}$

$\mathrm{Fe}-20 \% \mathrm{Cr}$

AISI409

AISI 303

AISI 304

AISI 304

AISI 304

AISI316

AISI316

AISI321

\section{$\underline{\text { Steels }}$}

\section{$0.5 \mathrm{M} \mathrm{HCl}$ \\ $1 \mathrm{M} \mathrm{H}_{2} \mathrm{SO}_{4}$ \\ $0.62 \mathrm{M} \mathrm{NaCl}$ \\ Hanks sol.}

Modified Livingston

$1 \mathrm{M} \mathrm{H}_{2} \mathrm{SO}_{4}, 0.5 \mathrm{M} \mathrm{NaCl}$

Modified Livingston

Modified Livingston

$0.01 \mathrm{M}$ borax sol.

$\mathrm{Na}_{2} \mathrm{SO}_{4}+10^{3} \mathrm{ppm}$
$200 \mathrm{~nm}$

$15 \mathrm{~nm}$

$15 \mathrm{~nm}$

$55 \mathrm{~nm}$

10-20 nm

$80-120 \mathrm{~nm}$

$20 \mathrm{~nm}$$$
\text { - }
$$

$20 \mathrm{~nm}$

20-70 nm

20-70 nm

$15 \mathrm{~nm}$

$350 \mathrm{~nm}$
-
$250 \mathrm{~nm}$
$200-300 \mathrm{~nm}$
-

Pure Iron

Pure Iron

Mild steels

IF-Steels

IF-Steels

F-Steels

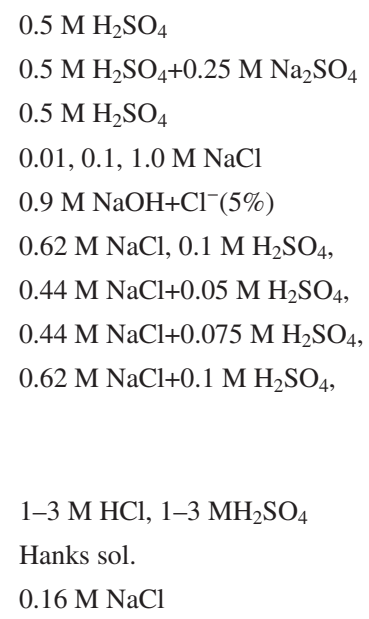

1-3 M HCl, 1-3 $\mathrm{MH}_{2} \mathrm{SO}_{4}$

Hanks sol.

$0.16 \mathrm{M} \mathrm{NaCl}$

\section{Titanium}

$\mathrm{Ti}(>99.36 \%)$

CP-Ti

Better

Mar. better

Worse

Depends

Better

Better $(0.6 \mathrm{M})$

Worse (2.5)

Better (0.1 M),

Better

Better (AE42)

Worse (AE21)

Better

Better

Better
Equal
Worse
Equal
Mar. better
Equal
Better
Equal
Mar. better
Worse

MA 95)

ECAP 96)

ECAP 97)

ECAP 6)

ECAP 98)

ECAP 101)

ECAP 102)

ECAP 104)

ARB 105)

PM 180)

$\begin{array}{lll}\text { Better } & \text { ECAP } & 181) \\ \text { Better } & \text { PM } & 126) \\ \text { Better } & \text { PM } & 130) \\ & & \\ \text { Depends } & \text { SMAT } & 73) \\ \text { Worse } & \text { HE } & 185) \\ \text { Better } & \text { ECAP } & 124) \\ \text { Better } & \text { SB } & 78) \\ \text { Better } & \text { ECAP } & 182) \\ \text { Equal } & \text { HE } & 184) \\ \text { Better } & \text {.HE } & 127) \\ \text { Worse } & \text { HE } & \\ \text { Equal } & \text { UP } & 77)\end{array}$

$\begin{array}{lll}\text { Better } & \text { ECAP } & \text { 107) } \\ \text { Better } & \text { SR } & \text { 76) } \\ \text { Better } & \text { ECAP } & \text { 107) } \\ \text { Equal } & \text { ECAP } & { }^{183)} \\ \text { Better } & & \\ \text { Better } & \text { WB } & \text { 47) } \\ \text { Better } & & \\ \text { Better } & & \\ \text { Better } & & \end{array}$

$300 \mathrm{~nm}$.

300-500 nm

$260 \mathrm{~nm}$
Mar. better

Mar. better

Mar. better $\begin{array}{ll}\text { ECAP } & 108) \\ \text { ECAP } & 109) \\ \text { ECAP } & 110)\end{array}$

ECAP 110) 


$\begin{array}{lll}\text { CP-Ti } \text { (grade 2) } & \text { A } & 0.15 \mathrm{M} \mathrm{NaCl} \\ \text { CP-Ti (grade 2) } & \text { A } & 0.62 \mathrm{M} \mathrm{NaCl} \\ \text { CP-Ti (grade 2) } & \text { A } & 0.5 \mathrm{M} \mathrm{H}_{2} \mathrm{SO}_{4} \\ \text { CP-Ti (grade 2) } & \text { A } & 1 \mathrm{M} \mathrm{H}_{2} \mathrm{SO}_{4}, 1 \mathrm{M} \mathrm{HCl} \\ \text { Ti-Zr-Ta-Nb } & \text { C } & \text { Ringer's sol. } \\ \text { Ti-13Nb-13Zr } & \text { D } & \text { Hank's sol. }\end{array}$

$\begin{array}{ll}90 \mathrm{~nm}+\text { disl. } & \text { Worse } \\ 110 \mathrm{~nm} & \text { Equal } \\ 200-500 \mathrm{~nm} & \text { Better } \\ 200-500 \mathrm{~nm} & \text { Better } \\ - & \text { Better } \\ 644 \mathrm{~nm}(\alpha) & \text { Better } \\ 590 \mathrm{~nm}(\beta) & \end{array}$

HE 111)

HPT 112)

HRDSR 113)

HRDSR 114)

ARB 186)

ECAP 155)

\section{Zirconium}

\begin{tabular}{llllll}
$\mathrm{Zr}-2.5 \mathrm{Nb}$ & $\mathrm{B}$ & $0.62 \mathrm{M} \mathrm{NaCl}$ & $150-200 \mathrm{~nm}$ & Mar. better & UP \\
$\mathrm{Zr}-1 \mathrm{Nb}$ & $\mathrm{B}$ & $0.62 \mathrm{M} \mathrm{NaCl}$ & $100-200 \mathrm{~nm}$ & Mar. better & UP \\
\hline
\end{tabular}

$\mathrm{SPD}$; ECAP=equal channel angular pressing, $\mathrm{ARB}=\mathrm{Accumulative}$ roll bonding, $\mathrm{HE}=\mathrm{Hydraulic}$ extrusion,

$\mathrm{HPT}=$ High pressure torsion, $\mathrm{CrR}=$ Cryo rolling, $\mathrm{CrM}=\mathrm{Cryo}$ milling, SMAT=Surface mechanical attrition treatment,

$\mathrm{DDE}=$ Dual directional extrusion, $\mathrm{BU}=$ Burnishing, HRDSR=High ratio differential rolling,

$\mathrm{UP}=\mathrm{Ultrasonic}$ peening, $\mathrm{SR}=$ Severe rolling, $\mathrm{WB}=$ Wire brushing, $\mathrm{SB}=$ Sand blast, $\mathrm{MA}=$ Machining

"Better" means that UFG shows higher corrosion resistance than the coarse grain counterpart, and "Worse" is vice versa.

"Depends" means that superiority depends on conditions of SPD processing or corrosion tests.

Hanks solution; $0.185 \mathrm{~g} / \mathrm{L} \mathrm{CaCl}_{2}, 0.4 \mathrm{~g} / \mathrm{L} \mathrm{KCl}, 0.06 \mathrm{~g} / \mathrm{L} \mathrm{KH}_{2} \mathrm{PO}_{4}, 0.1 \mathrm{~g} / \mathrm{L} \mathrm{MgCl}{ }_{2} 6 \mathrm{H}_{2} \mathrm{O}, 0.1 \mathrm{~g} / \mathrm{L} \mathrm{MgSO} 47 \mathrm{H}_{2} \mathrm{O}, 8.0 \mathrm{~g} / \mathrm{L} \mathrm{NaCl}, 0.35 \mathrm{~g} / \mathrm{L} \mathrm{NaHCO}, 0.48$ $\mathrm{Na}_{2} \mathrm{HPO}_{4}, 1.0 \mathrm{~g} / \mathrm{L}$ D-glucose, $\mathrm{pH}=7.4$

Ringer's solution; 0.20 g/L CaCl, 0.4 g/L KCl, 0.2 g/L MgSO $47 \mathrm{H}_{2} \mathrm{O}, 6.8 \mathrm{~g} / \mathrm{L} \mathrm{NaCl}, 1.0 \mathrm{~g} / \mathrm{L} \mathrm{NaHCO}, 0.14$ Na $2 \mathrm{HPO}_{4}, 1.0$ g/L D-glucose, pH = 6.9

Livingston' etchant; $30 \mathrm{~mL} \mathrm{HCL}, 10 \mathrm{~mL} \mathrm{CH} \mathrm{COOH}_{3} 410 \mathrm{~mL} \mathrm{H}_{2} \mathrm{O}\left(0.48 \mathrm{M} \mathrm{HCl}, 0.40 \mathrm{M} \mathrm{CH}_{3} \mathrm{COOH}\right)$

1) Type $C$ and $D$ are also belong to $B$ in alloys, therefore $B$ is omitted.

2) All the units of concentration in the literature are unified and expressed by $\mathrm{M}(=\mathrm{mol} / \mathrm{L})$ for comparison although many papers express the concentration of $\mathrm{NaCl}$ by mass\%.

3) Change in corrosion resistance as grain size decreases by SPD

cussed later.

\subsection{Aluminum and aluminum alloys}

Aluminum and its alloy are readily passivated and become stable in neutral solution, but dissolve in acidic and alkali solution. Pitting tends to occur in neutral solution with chloride ion. Majority of papers report that the UFG materials in passive media exhibit higher corrosion resistance following the Ralston's rule ${ }^{44)}$, its superiority manifests itself by breakdown potential rather than passive current. However, there is some inconsistency among the literature, even for pure aluminum, reporting favorable effect of $\mathrm{UFG},{ }^{89,92,171)}$ marginal change, ${ }^{158)}$ unfavorable effect. ${ }^{87,93,158,162)}$ The favorable effect is attributed to the readily formation of oxide film because atoms at grain boundaries site are reactive to chemical species in the environment. ${ }^{89,92,171)}$ One possible explanation for this contradictory results is the purity; lower purity may results in the degradation of corrosion properties by SPD. Eizadjouet $e t$ $a l .{ }^{93)}$ attributed lower corrosion resistance to refinement of $\mathrm{Al}_{3} \mathrm{Fe}, \mathrm{Al}_{6} \mathrm{Fe}$ intermetallics and related defective passive films. Pitting corrosion resistance of aluminum alloys with precipitation or the second phase (type $\mathrm{D}$ ) is mostly improved by SPD, $45,75,87,92,120,121,143,150-153,156,158,167)$, and this improvement is mainly due to physical breakup of the second phase or precipitation which differs in dissolution potential from the matrix and causes defective structure of passive film. For example, pitting occurs at the interface between the matrix and nobler second phase. ${ }^{88,150-152,160)}$ When the precipitation is smaller than critical size, it does not work as a nucleation site of pitting. Effect of refinement of the second phase on corrosion is more evident in eutectic ${ }^{153)}$ and hypereutectic Al-Si alloys ${ }^{151)}$ where nobler hard Si-phase was finely redistributed during SPD, resulting in the more uniform corrosion. The physical breakup of the second phase also involve refinement or homogenization of solute-depleted zones, which results in improvement in corrosion resistance. ${ }^{87,156)}$

Combined effect of UFG and precipitation on strengthening can be expected by an appropriate processing comprising SPD and post-SPD artificial or natural aging in order to achieve higher strength due to very fine precipitation in UFG microstructures. ${ }^{137,144)}$ The formation of finer $\theta$-phase precipitation in UFG Al-Cu materials at the post-SPD aging treatment lead to smaller or disappearance of $\mathrm{Cu}$-depleted zone. $^{75,87,150)}$ Indeed, Jilani, ${ }^{159)}$ Kus ${ }^{163)}$ and Brunner ${ }^{150)}$ reported transition from intergranular corrosion to pitting corrosion with decreasing grain size into a submicron scale. There are also some few opposing studies reporting unfavorable effect of SPD on corrosion of aluminum alloys. ${ }^{160,162,167,169)}$ Son et al. attribute its effect to internal stress induced by SPD, which break the oxide film and induce the pitting at defects of the oxide films. Korchef et al. ${ }^{162)}$ explained the decrease of pitting corrosion resistance by the physical breakup of precipitation and increasing number of metal/precipitation interface where pitting starts to form. In summary, the physical fragmentation of precipitates by SPD appears to be double-edge swords for corrosion in aluminum alloys, and contradicting reports are concentrated in type D materials.

\subsection{Magnesium and magnesium alloys}

More papers are reporting the favorable effect of SPD on corrosion properties than those opposing. Those reporting unfavorable effect are many in type D, but the role of precipitation appears to be not important in magnesium alloys. Effect 
for magnesium alloys is rather complex for several reasons; (i) unstable passive film, (ii) heterogeneous structures as a result of dynamic recrystallization, and (iii) strong texture dependency. Firstly, magnesium forms oxide or hydroxide film in neutral or alkali solutions, and they are unstable and time-dependent. EIS reveals that time-dependency of stability and anomalous change of permeability, either progressing $^{122,123)}$ or regressing ${ }^{154)}$ or both ${ }^{175)}$ with immersion time for UFG materials. Therefore, evaluation of corrosion dependence either by polarization or immersion tests must be careful. Secondly, magnesium is the close-packed hexagonal structure, and is hard to deform at room temperature. Therefore, they are generally deformed by SPD at relatively high temperatures ranging from 200 to $300^{\circ} \mathrm{C}$. As shown in Table 2, the final grain size of SPD magnesium alloys is rather large ranging from 1 to several micron meters as compared with other UFG metals. Processing at relatively higher homologous temperature cause dynamic recrystallization during SPD processing, ${ }^{27,177,187-189)}$ and this may render the microstructure inhomogeneous mixed with recrystallized and severely deformed microstructures. ${ }^{27,187)}$ The degree of mixture depends on the pressing temperature and starting grain size. $^{27,187)}$ It seems that contradicting studies reporting inferior corrosion resistance after SPD of pure magnesium, ${ }^{116}$ ) $\mathrm{AZ31},{ }^{176,189)}$ (type B) may be attributed to the inhomogeneous microstructures related with dynamic recrystallization. Finally, crystallographic orientation dependency of corrosion is very high in magnesium alloys, ${ }^{83,190-198)}$ and it seems to have higher impact than grain size. The high atomic coordination of basal plane make the electron working function higher, and has the highest resistance to dissolution. Texture is dependent on deformation routes, SPD technique, thus, it is hard to draw general conclusion on corrosion resistance.

\subsection{Copper and copper alloys}

Copper is a noble metal and exhibits passivity in neutral solutions, and it can be dissolve in acidic and alkali solutions with high oxidizing power. Effect of UFG formation on corrosion have mostly been investigated on copper of commercial purity, and is overall very small in all electrolytes tested. ${ }^{6,95-98,101,102,104,105,180)}$ Pure copper is the best suitable metal for studies using dislocation etchant, ${ }^{199-201)}$ which attack only crystal defects such as edge dislocations and grain boundaries and leaves other parts intact. Hinted by this, UFG pure copper by ECAP was immersed in modified Livingston etchant in an effort to extract the effect of grain size on dissolution in the active state. ${ }^{98)}$ Therefore the initial expectation is that UFG copper with high grain boundaries density corrode faster than the coarse grain counterpart following the Ralston's rule. Surprisingly the result is opposite and against Ralston's rule, and the corrosion current is lower in as-ECAPed UFG copper than that in the coarse-grain counter materials because of suppressed cathode current and unchanged anode current (Fig. 3). This result can be explained by micro local-cells between grain boundaries and the grain interior. When grain size become smaller in submicron scale, areas for cathode sites are not enough as compared with coarse grained copper. Detailed mechanism is discussed later. Annealling ECAPed copper for very short time of $90 \mathrm{~s}$ at $200^{\circ} \mathrm{C}$ with little grain size change increased corrosion rate. The corroded surface of

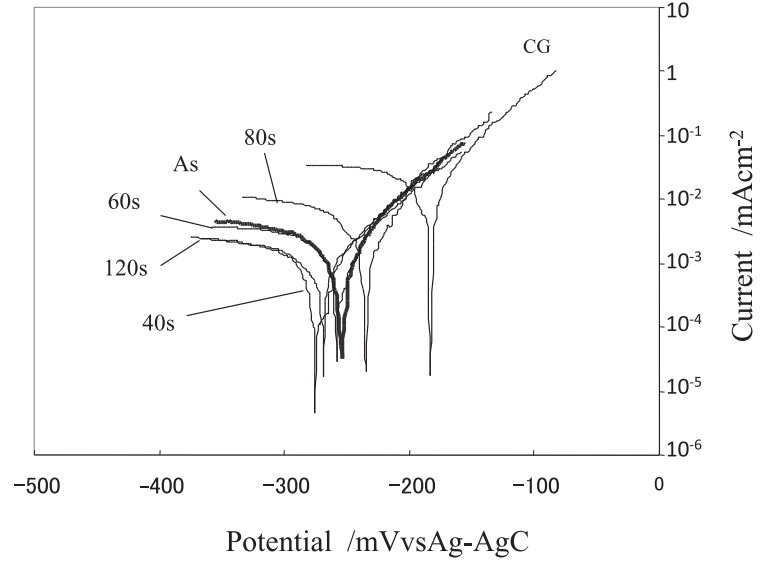

Fig. 3 Dynamic polarization curves of as-ECAPed UFG and post-ECAP annealed copper by $200^{\circ} \mathrm{C}$ for $40-120$ seconds. $^{98)}$

as-ECAPed copper was relatively smoother than those of annealed and coarse-grained ones, and it suggests transition from uniform to intergranular mode of corrosion.

\subsection{Pure iron and steels}

In this class of materials, all the literature without exception, though not so many, follow the Ralston's rule. Zhang et al. ${ }^{107)}$ investigated anodic polarization behavior of UFG mild steels $(\mathrm{C} ; 0.10-0.13 \mathrm{wt} \%)$ and pure iron produced by ECAP, and found that both have better passivity than as-cast counterparts. Similarly to aluminum, the densely populated crystalline defects in the UFG structures become the nucleation sites of the passive film, which improved passivity properties. Additionally, the refinement of iron carbide particles during ECAP processing contributes to the formation of continuous dense passive film in UFG mild steels. ${ }^{107)}$ The more protective passive layer are also reported in UFG IF steels, ${ }^{183)}$ as evidenced by higher pitting potential in $0.9 \mathrm{NaOH}+\mathrm{Cl}^{-}$solutions and in pure iron by EIS. ${ }^{76)}$ Dehghani et al. ${ }^{47)}$ reported polarization behavior of IF steels in the active region in a wide range of $\mathrm{pH}$ which was controlled by mixing $3.5 \% \mathrm{NaCl}$ and $0.1 \mathrm{M} \mathrm{H}_{2} \mathrm{SO}_{4}$. Nanograined IF steels exhibited smaller corrosion current in a wide range of $\mathrm{pH}$ as a result of more protective surface layer. ${ }^{47}$ )

\subsection{Stainless steels}

To the best of my knowledge, stainless steels are the most benefitted materials by SPD. Essentially all the literature with few exception ${ }^{127,185)}$ reported the higher corrosion resistance of UFG stainless steels regardless of SPD processing. Mostly, UFG materials follow the Ralston's rule ${ }^{44)}$ exhibiting lower passive current and higher breakdown potential in $\mathrm{Cl}^{-}$containing solutions. As for the corrosion of nanocrystalline stainless steels, please refer to an excellent review by Guputa. ${ }^{55)}$ This higher stability of passivation is attributed to higher $\mathrm{Cr}$ concentration (high $\mathrm{Cr} / \mathrm{Fe}$ ) in the surface of nanocrystalline structure ${ }^{126,130,131)}$, and high $\mathrm{Cr}$ enrichment in nanocrystalline structure is speculated to be caused by higher fraction of grain boundaries which provide faster diffusion path for $\mathrm{Cr}^{131)}$, although other view is presented by Gupta that $\mathrm{Cr}$ enrichment is caused by selective dissolution of Fe. ${ }^{126)}$ The only opposing report ${ }^{185)}$ attributed the inferior corrosion resistance 


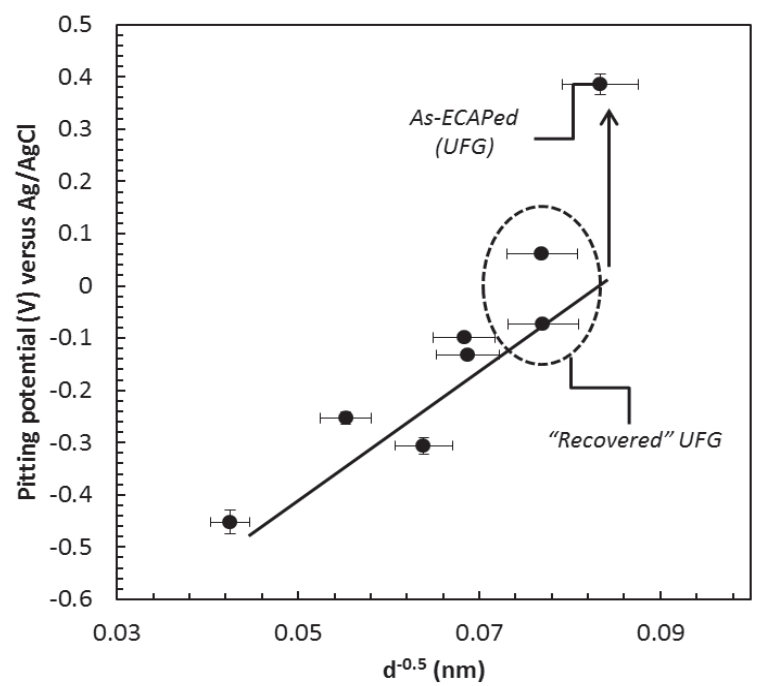

Fig. 4 Relation between pitting potential and grain size in high purity UFG $\mathrm{Fe}-20 \% \mathrm{Cr}$ alloys fabricated by ECAP. Grain size are controlled by postECAP annealing. ${ }^{181)}$

to high amount of $\mathrm{MnS}$ inclusions, which are physically broken up into finer size during ECAP and provide more nucleation size for pitting. Rifai et al. ${ }^{181)}$ investigated corrosion behavior of UFG Fe-20\%Cr steels by ECAP, and effect of grain size controlled by post-ECAP annealing on pitting potential. It was found that pitting potential of as-ECAP was highest and decreased with increasing temperature of the post-ECAP annealing. The pitting potential of a series of the annealed materials decreased with increasing grain size and followed the so-called Hall-Petch type relationship, but the pitting potential of as-ECAPed was higher than that of annealed materials in spite of the comparable grain size as shown in Fig. 4. Higher corrosion resistance of as-ECAPed UFG than "recovered" UFG with the same grain size is noteworthy results, and is not clarified yet. As pointed out by Pan, ${ }^{131}$ ) fast diffusion of $\mathrm{Cr}$ through non-equilibrium grain boundaries and resultant $\mathrm{Cr}$ enrichment are speculated to be the reason for higher corrosion resistance. Alternatively selective dissolution of $\mathrm{Fe}$ due to high density of non-equilibrium grain boundaries may be accelerated, which result in higher $\mathrm{Cr}$ concentration and passivity. Oppositely, favorable effect of such short-time recovering treatment on corrosion resistance is reported in pure titanium ${ }^{113)}$ and in magnesium alloy. ${ }^{202)}$

\subsection{Titanium alloy}

Titanium alloy is the most corrosion-resistant alloy among the structural materials with the very high stable passive film formation. In this class of materials, mostly pure titanium of commercial purity has been pressed by SPD for UFG formation for biomedical applications. ${ }^{108-114)}$ Pure titanium have good affinity with human bodies, and the strength can be boosted by SPD without sacrificing the affinity and corrosion resistance. On the other hand, titanium alloys are mostly very hard and have high strength, thus studies on these have been very limited. ${ }^{155,186)}$ The literature ${ }^{108-114,155,186)}$ on corrosion resistance of UFG pure titanium unanimously shows a little higher corrosion resistance than coarse-grained counterparts except for one paper ${ }^{111)}$ which report inferior corrosion prop- erty of UFG titanium processed by hydraulic extrusion. The corrosion properties were mostly investigated by potentio-dynamic polarization or weight loss experiment by immersion tests. The passivity of UFG titanium follows the Ralson's rule $^{44)}$ and is more stable as evidenced by lower passive current with marginal difference in dynamic polarization, but superiority is more explicit in weight loss experiment. ${ }^{108,113,114)}$ As is described in magnesium alloy, the effect of texture on corrosion is strong because of the basal plane being most resistant to corrosion, ${ }^{109,110)}$ thus letting UFG effect be more dependent on specific SPD and processing route.

\section{Effect of Grain Size}

From the thermodynamic principle of electrochemistry, UFG materials have lower dissolution potential and therefore higher tendency to dissolution in aggressive media than coarse-grained counterparts because the former has high density of grain boundaries and higher internal energy. However, kinetics of corrosion is related with the mode of corrosion such as general or uniform corrosion, intergranular and pitting corrosion, and detailed micromechanism of electrochemical reaction is related with microstructure including inhomogeneity of impurity, solute elements and precipitation as well as grain size.

Let us consider a simple pure metal composed of grain boundaries and grain interior with different dissolution potentials, and it is under an active state in an acidic media. When the acidic media is aggressive, and the oxidizing power, i.e. the half-cell electrode potential of oxidizing agent, is higher than the dissolution potential of both grain boundaries and grain interior, then dissolution proceed in a uniform manner with little localization. However, oxidizing power is weaker, and its equilibrium electrode potential is ideally lower than dissolution potential of grain interior, and higher than that of grain boundaries, then dissolution proceed in a local manner, by forming local cell between grain boundaries and grain interior. In the former case, corrosion rate may increase with decreasing grain size and thus increasing grain boundary area because of high energy state of the atoms at the defective structures. On the other hand, in the latter case, corrosion rate may start to decrease with decreasing grain size when grain size become smaller than a certain critical size as shown in Fig. 5. Under the critical grain size, cathode area cannot counter the increasing grain boundary area as the anode site, resulting in the suppression of the cathode reaction. This grain size dependency become pronounced when corrosion kinetics is controlled by cathodic reaction such as diffusion of dissolved oxygen. This may be the reason why the corrosion of UFG pure copper in Livingston's dislocation etchant is slower than that of coarse grain copper as described in the previous section. ${ }^{98)}$ An extreme case may be the low rate of intergranular corrosion of austenitic stainless steel. ${ }^{41-43)}$ Whether grain size dependency of corrosion rate become positive or negative is decided by the degree of locality of corrosion regardless of active or passive state.

\section{Effect of Internal Stress}

Another important factor which may impact corrosion re- 


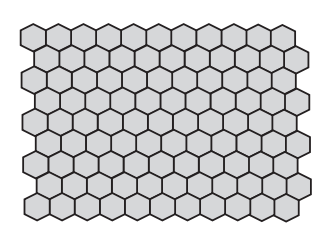

(d)

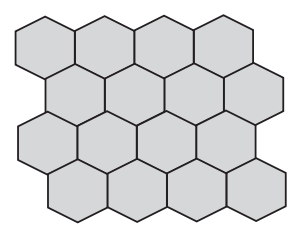

(c)

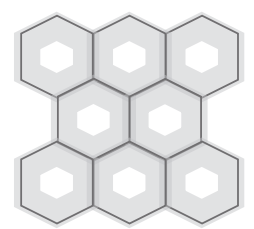

(b)

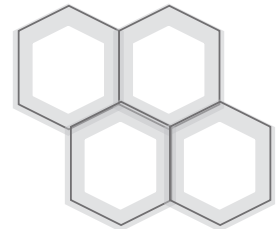

(a)
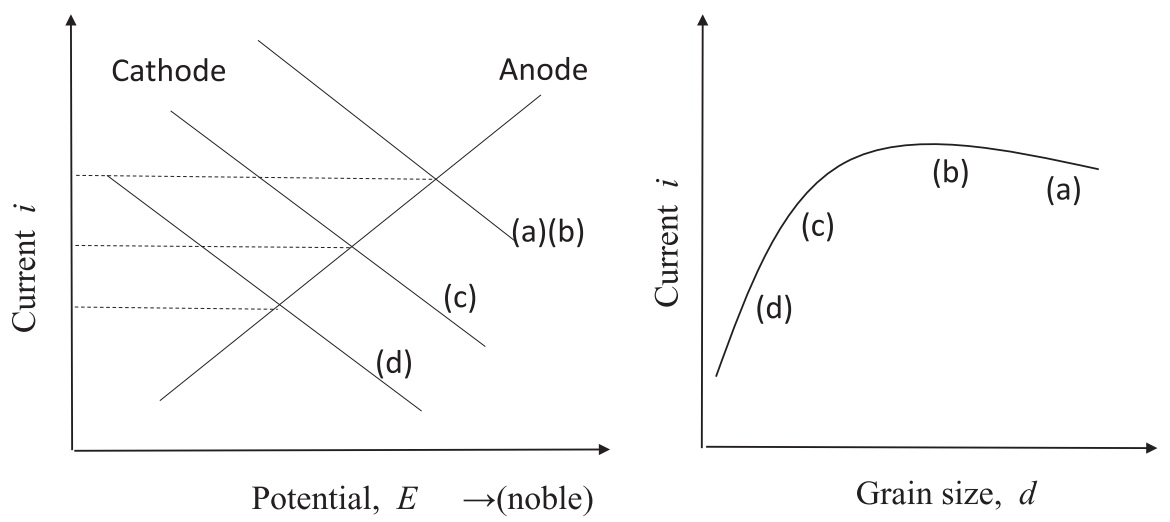

Fig. 5 Schematic diagram showing change in area distribution of cathode area (shadow area) and corrosion current with decreasing grain size under active dissolution. With decreasing grain size, the cathode area decrease while anode area increases, and the former do not counter the latter under the critical grain size, which leads to reduction of corrosion current.

sistance and may occur commonly in SPD is residual stress (generally macroscopic) and internal stress (microscopic). Those two notions are similar and frequently seem to be confused in the literature. ${ }^{44)}$ For example, Ralston ${ }^{44)}$ discussed the effect of residual stress on corrosion, and this "residual stress" seems to include both. In the former case in a common sense, tensile and compressive stress fields are distributed in macroscopic scale between, i.e., the surface and interior of components. The residual stress is more familiar than the latter for materials engineers, and arises from inhomogeneous thermal history and plastic strain that occurs in a common form of thermomechanical processing. On the other hand, the notion of internal stress is rather new, and considered to arise from deformation-induced microstructures, and its tensile and compressive stress fields are microscopic and distributed in grain-size scale., ${ }^{9}$ 203-205) The existence of high internal stress was evidenced by X-ray diffraction, ${ }^{203-205)}$ fringe contour visible in bright-field images by TEM. ${ }^{11,13,204,206-208)}$ These contour appears as a result of curvature of foil strained by high internal stress. The high internal stress has often attributed to the so-called non-equilibrium grain boundaries $^{9,11-15,205,206,208,209)}$ although there are other views. ${ }^{203,204)}$ Grain boundaries generated by plastic deformation are at high-energy state with excessive grain boundaries dislocations, or alternatively called extrinsic grain boundary dislocations that extend long-range stress field into the grain interior. $^{208)}$ The notion of the non-equilibrium grain boundaries was originally proposed by Grabski, ${ }^{10)}$ and was later demonstrated in UFG structure by TEM. ${ }^{12-15)}$ The high energy non-equilibrium grain boundaries cause fast diffusion, ${ }^{16-21,210}$ ) and resultant room temperature grain boundary sliding in pure aluminum as evidenced by topographical observation by atomic force microscopy. ${ }^{22,32)}$ Under the high internal stress, atoms at the surface are at a high free energy state with low electron work function of the surface. This facilitates either anodic dissolution or the formation of passive film. ${ }^{44,211)}$ The high internal stress can be relieved by annealing for the short time and at low temperature with little grain size change, ${ }^{9,203-206)}$ possibly accompanying transition from the non-equilibrium to an equilibrium state by dissipating extrinsic grain boundary dislocations. ${ }^{16,209,212-214)}$ The time required for grain boundary equilibration in pure nickel is estimated to be $40 \mathrm{~s}$ at $250^{\circ} \mathrm{C}$ in low segregation level while 1200 to $5000 \mathrm{~s}$ at $250^{\circ} \mathrm{C}$ in high segregation, and the time depends on the degree of segregation and grain boundary character. ${ }^{214)}$ This is in contrast with the classic residual stress that requires heat treatment of several hours to be relieved. There are several experimental results that corrosion rate increased by the post-SPD short annealing aiming to relieve internal stress, ${ }^{98,104,181)}$ and these suggests that high internal stress, or non-equilibrium grain boundaries, or both concurrently, improve corrosion resistance. Miyamoto et al. examined the corrosion behavior of UFG copper by ECAP in a modified Livingston's dislocation etchant, and it is surprising that corrosion current increase by the post-ECAP annealing of the temperature of $200^{\circ} \mathrm{C}$ for 90 seconds with little grain size change. ${ }^{98)}$ It is interesting to note that the corroded surface of UFG copper is rather uniform while that in annealed one is rougher, suggesting transition from uniform to intergranular mode of corrosion. This mode change can be interpreted in terms of the local-cells between grain boundaries and grain interior and energy difference between two. Namely, the annealing relieves the internal stress and decreases the free energy of grain interiors, which increases the energy difference between two, resulting in intergranular mode of corrosion. It is unlikely that macroscopic residual stress caused by plastic strain can be relieved by this short time annealing.

However, internal stress and possibly residual stress in a 
Table 3 Summary of SCC experiments of UFG materials by SPD.

\begin{tabular}{|c|c|c|c|c|c|c|}
\hline Materials & Environment & Grain size & Type of test & Susceptibility ${ }^{1)}$ & SPD & Ref. \\
\hline Al-Mg & $3 \% \mathrm{NaCl}$ & - & SSRT & Better & ECAP & 164) \\
\hline $\mathrm{Al}-\mathrm{Mg}-\mathrm{Sc}$ & $3.5 \% \mathrm{NaCl}$ & $0.39 \mu \mathrm{m}$ & SSRT & Worse & FSP & 86) \\
\hline $\mathrm{CP} \mathrm{Cu}$ & $1 \mathrm{M} \mathrm{NaNO}_{2}$ & $0.3 \mu \mathrm{m}$ & SSRT & Better & ECAP & 102) \\
\hline $\mathrm{CP} \mathrm{Cu}$ & $1 \mathrm{M} \mathrm{NaNO}_{2}$ & $200 \mathrm{~nm}$ & SSRT & Better & ECAP & 103) \\
\hline $\mathrm{Cu}-10 \% \mathrm{Zn}$ & Ammonia & $200 \mathrm{~nm}$ & CLT & Worse & ECAP & 216) \\
\hline AZ31 & $3.5 \% \mathrm{NaCl}$ & $0.63 \mu \mathrm{m}$ & SSRT & Worse & FSP & 85) \\
\hline SUS304 & Boiled $\mathrm{MgCl}_{2}$ & & FPBT & $?$ & SG & 84) \\
\hline
\end{tabular}

Type of test:SSRT=slow strain rate technique, FPBS=Four points bending test, CLT=Constant load test

$\mathrm{SPD}$; ECAP=equal-channel angular pressing, $\mathrm{FSP}=$ friction stir processing, $\mathrm{SG}=$ surface griding,

1) Change as grain size decrease.

more common sense may play dual-edge roles as described in the previous section, i.e. acts as an enhancer by facilitating the passive film formation, or a degrader by introducing crack or defective film. ${ }^{44,169)}$ As the internal stress have dual-edge roles, so does the annealing intended for stress relief. Indeed, Kim et al. reported improvement of corrosion resistance in pure titanium $^{113)}$ and AZ61 ${ }^{202)}$ by annealing.

\section{Stress Corrosion Cracking (SCC) of UFG Materials}

SCC sensitivity of UFG materials by SPD has far less been studied as compared to corrosion property. One reason for this limited SCC studies of UFG materials is that structural materials which exhibit SCC are generally high alloys having high strength such as austenitic stainless steel and $\mathrm{Cu}-\mathrm{Zn}$ alloys, and hard to be processed by SPD. The other reason may be that observation of crack path and fracture surface by scanning electron microscopy is difficult because grain size is very small, making it difficult to identify SCC mechanism. Table 3 summarize the published papers list of SCC studies of UFG materials. As shown in Table 3, SCC of UFG materials have been investigated by mostly slow-strain-rate-test (SSRT), and sensitivity to SCC is evaluated by the ratio of elongation to fracture in air and solution. As differing from corrosion, there are no systematic study reporting on effect of grain size on SCC sensitivity using a wide range of grain size. The existing literature are divided into two groups reporting favorable and unfavorable effect of UFG formation on SCC sensitivity. It should be pointed out that time-dependent deformation of UFG become higher by fast diffusion at grain boundaries as evidenced by room-temperature grain boundary sliding ${ }^{22)}$, discrepancy of SCC sensitivity become larger in accelerated SSRT test and the constant-load tests for UFG materials as compared with counter materials. More studies are being waited to find the trend of impact of UFG formation on SCC.

\section{Conclusions}

In general, strengthening through grain refinement by SPD does not sacrifice the corrosion resistance. Indeed, UFG Fe$\mathrm{Cr}$ alloys exhibit superior corrosion resistance than coarsegrain counterparts without exceptions while UFG copper and titanium are relatively comparable with coarse-grained mate- rials. SPD enhance the corrosion resistance through grain size reduction and homogenization of chemical inhomogeneity by the "shuffling" of severe plastic strain, and corrosion tends to change from local to uniform mode, i.e., intergranular to general corrosion, large pitting to smaller or shallower ones. On the other hand, aluminum and magnesium alloys, although majority papers report favorable effect of UFG formation, there are contradictory reports in similar materials and similar environment. The morphology of nobler precipitates such as size and distribution has impact on micro-scale electrochemical polarization, which results in better or inferior corrosion performance. Additionally, magnesium alloys are more sensitive to microstructural change specific to SPD processing. Nevertheless, change to more structural homogeneity accompanied with grain size reduction have high potential for higher corrosion performance.

\section{REFERENCES}

1) I. Sabirov, M.Y. Murashkin and R.Z. Valiev: Mater. Sci. Eng. A 560 (2013) 1-24.

2) R.Z. Valiev, R.K. Islamgaliev and I.V. Alexandrov: Prog. Mater. Sci. 45 (2000) 103-189.

3) R.Z. Valiev and T.G. Langdon: Prog. Mater. Sci. 51 (2006) 881-981.

4) T.G. Langdon: Acta Mater. 61 (2013) 7035-7059.

5) Y. Estrin and A. Vinogradov: Acta Mater. 61 (2013) 782-817.

6) X.X. Xu, F.L. Nie, J.X. Zhang, W. Zheng, Y.F. Zheng, C. Hu and G. Yang: Mater. Lett. 64 (2010) 524-527.

7) V. Latysh, G. Krallics, I. Alexandrov and A. Fodor: Curr. Appl. Phys. 6 (2006) 262-266.

8) T. Lee, Y.-U. Heo and C.S. Lee: Scr. Mater. 69 (2013) 785-788.

9) A.A. Nazarov, A.E. Romanov and R.Z. Valiev: Nanostructured Materials 4 (1994) 93-101.

10) M.W. Grabski and R. Korski: Philos. Mag. 22 (1970) 707-715.

11) R.Z. Valiev, R.S. Musalimov and N.K. Tsenev: Pys. Stat. Sol. 115 (1989) 451 (a).

12) Z. Horita, D.J. Smith, M. Furukawa, M. Nemoto, R.Z. Valiev and T.G. Langdon: Mater. Charact. 37 (1996) 285-294.

13) K. Oh-ishi, Z. Horita, D.J. Smith and T.G. Langdon: J. Mater. Res. 16 (2001) 583-589.

14) Z. Horita, D.J. Smith, M. Furukawa, M. Nemoto, R.Z. Valiev and T.G. Langdon: J. Mater. Res. 11 (1996) 1880.

15) Z. Horita, B.C. Smith, M. Nemoto, R. Valiev and T.G. Langdon: J. Mater. Res. 13 (1998) 446-450.

16) S.V. Divinski, G. Reglitz, I.S. Golovin, M. Peterlechner, R. Lapovok, Y. Estrin and G. Wilde: Acta Mater. 82 (2015) 11-21.

17) S.V. Divinski, G. Reglitz, H. Rösner, Y. Estrin and G. Wilde: Acta Mater. 59 (2011) 1974-1985.

18) J. Fiebig, S. Divinski, H. Rosner, Y. Estrin and G. Wilde: J. Appl. Phys. 
110 (2011) $0835141-8$.

19) V.N. Perevezentsev: Phys. Met. Metallogr. 93 (2002) 207-210.

20) V.N. Perevezentsev and A.S. Pupynin: Phys. Met. Metallogr. 105 (2008) 322-326.

21) Z.B. Wang, N.R. Tao, W.P. Tong, J. Lu and K. Lu: Acta Mater. 51 (2003) 4319-4329.

22) N.Q. Chinh, P. Szommer, Z. Horita and T.G. Langdon: Adv. Mater. 18 (2006) 34-39.

23) X.Z. Liao, Y.H. Zhao, R. Srinivasan, Y.T. Zhu, R. Valiev and D.V. Gunderov: Appl. Phys. Lett. 84 (2004) 592-594.

24) Y. T. Zhu and X. Z. Liao: nature materials 3 (2004) 351-352.

25) Y.H. Zhao, J.F. Bingert, X.Z. Liao, B.Z. Cui, K. Han, A.V. Sergueeva, A.K. Mukherjee, R. Valiev, G. Langdon and Y.T. Zhu: Adv. Mater. 18 (2006) 2949-2953.

26) Y.M. Wang and E. Ma: Acta Mater. 52 (2004) 1699-1709.

27) R.B. Figueiredo and T.G. Langdon: Mater. Sci. Eng. A 501 (2009) 105-114.

28) S. Okubo, Y. Miyajima, T. Fujii, S. Onaka and M. Kato: Trans. JIM 54 (2013) 1605-1611.

29) Q. Wei: J. Mater. Sci. 42 (2007) 1709-1727.

30) H. Miyamoto, K. Ota and T. Mimaki: Scr. Mater. 54 (2006) 1721-1725.

31) H. Ueno, K. Kakihata, Y. Kaneko, S. Hashimoto and A. Vinogradov: Acta Mater. 59 (2011) 7060-7069.

32) A. Vinogradov and S. Hashimoto: Trans. JIM 42 (2001) 74-84.

33) K.D. Ralston, N. Birbilis and C.H.J. Davies: Scr. Mater. 63 (2010) 1201-1204.

34) K.D. Ralston, G. Williams and N. Birbilis: Corrosion 68 (2012) $507-$ 517.

35) K.D. Ralston, D. Fabijanic and N. Birbilis: Electrochim. Acta 56 (2011) 1729-1736.

36) S. Gollapudi: Corros. Sci. 62 (2012) 90-94.

37) W. Luo, Y. Xu, Q. Wang, P. Shi and M. Yan: Corros. Sci. 52 (2010) 3509-3513.

38) X.Y. Zhang, M.H. Shi, C. Li, N.F. Liu and Y.M. Wei: Mater. Sci. Eng. A 448 (2007) 259-263.

39) R. Mishra and R. Balasubramanian: Corros. Sci. 46 (2004) 3019-3029.

40) T.C. Tsai and T.H. Chuang: Mater. Sci. Eng. A 225 (1997) 135-144.

41) A. Di Schino and J.M. Kenny: J. Mater. Sci. Lett. 21 (2002) 19691971.

42) A. Di Schino, M. Barteri and J.M. Kenny: J. Mater. Sci. 38 (2003) 4725-4733.

43) A. Di Schino and J.M. Kenny: J. Mater. Sci. Lett. 21 (2002) 16311634.

44) K.D. Ralston and N. Birbilis: Corrosion 66 (2010) 075005 1-13.

45) K.D. Ralston, J.G. Brunner, S. Virtanen and N. Birbilis: Corrosion 67 (2011) 105001-105001-105010.

46) G.R. Argade, S.K. Panigrahi and R.S. Mishra: Corros. Sci. 58 (2012) 145-151.

47) K. Dehghani, M. Hosseini and A. Nekahi: Int. J. Mater. Res. 104 (2013) 999-1006.

48) L. Wang, J. Zhang, Y. Gao, Q. Xue, L. Hu and T. Xu: Scr. Mater. 55 (2006) 657-660

49) N.M. Pakhomova and I.A. Levin: Zashch. Metal 9 (1973) 676-700.

50) M. Alvarez-Lopez, M.D. Pereda, J.A. del Valle, M. Fernandez-Lorenzo, M.C. Garcia-Alonso, O.A. Ruano and M.L. Escudero: Acta Biomater. 6 (2010) 1763-1771.

51) V. Afshari and C. Dehghanian: Corros. Sci. 51 (2009) 1844-1849.

52) K.T. Liu and J.G. Duh: J. Electroanal. Chem. 618 (2008) 45-52.

53) R. Rofagha, U. Erb, D. Ostrander, G. Palumbo and K.T. Aust: Scr. Metall. Mater. 25 (1991) 2867-2872.

54) R. Rofagha, U. Erb, D. Ostrander, G. Palumbo and K.T. Aust: Nanostructured Materials 2 (1993) 1-10.

55) R.K. Gupta and N. Birbilis: Corros. Sci. 92 (2015) 1-15.

56) C. Koch: J. Mater. Sci. 42 (2007) 1403-1414.

57) L. Wang, Y. Lin, Z. Zeng, W. Liu, Q. Xue, L. Hu and J. Zhang: Electrochim. Acta 52 (2007) 4342-4350.

58) H. Ueno, K. Kakihata, Y. Kaneko, S. Hashimoto and A. Vinogradov: J. Mater. Sci. 46 (2011) 4276-4283.

59) B. Straumal, A.A. Mazilkin, B. Baretzky, G. Schutz, E. Rabkin and R Valiev: Trans. JIM 53 (2012) 63-71.

60) G. Sha, L. Yao, X. Liao, S.P. Ringer, Z. Chao Duan and T.G. Langdon: Ultramicroscopy 111 (2011) 500-505.
61) X. Sauvage, A. Ganeev, Y. Ivanisenko, N.A. Enikeev, M.Y. Murashkin and R.Z. Valiev: Adv. Eng. Mater. 14 (2012) 968-974.

62) C. Xu, M. Furukawa, Z. Horita and T.G. Langdon: Acta Mater. 53 (2005) 749-758.

63) C. Xu, M. Furukawa, Z. Horita and T.G. Langdon: Acta Mater. 51 (2003) 6139-6149.

64) M. Murayama, Z. Horita and K. Hono: Acta Mater. 49 (2001) 21-29.

65) M. Cabibbo, E. Evangelista and M. Vedani: Metall. Mater. Trans., A Phys. Metall. Mater. Sci. 36 (2005) 1353-1364.

66) Y. Miyajima, M. Mitsuhara, S. Hata, H. Nakashima and N. Tsuji: Mater. Sci. Eng. A 528 (2010) 776-779.

67) Y. Miyajima, T. Ueda, H. Adachi, T. Fujii, S. Onaka and M. Kato: IOP Conf. Ser. Mater. Sci. Eng. 63 (2014) 012138.

68) I.J. Beyerlein, R.A. Lebensohn and C.N. Tome: Mater. Sci. Eng. A 345 (2003) 122-138.

69) A. Gholinia, P. Bate and P.B. Prangnell: Acta Mater. 50 (2002) 21212136.

70) S. Ferrasse, V.M. Segal, S.R. Kalidindi and F. Alford: Mater. Sci. Eng. A 368 (2004) 28-40.

71) M. Haouaoui, K.T. Hartwig and A.E. Payzant: Acta Mater. 53 (2005) 801-810.

72) C. op't Hoog, N. Birbilis and Y. Estrin: Adv. Eng. Mater. 10 (2008) 579-582.

73) T. Balusamy, S. Kumar and T.S.N. Sankara Narayanan: Corros. Sci. 52 (2010) 3826-3834

74) M. Laleh and F. Kargar: J. Alloy. Compd. 509 (2011) 9150-9156.

75) K. Gopala Krishna, K. Sivaprasad, T.S.N. Sankara Narayanan and K.C. Hari Kumar: Corros. Sci. 60 (2012) 82-89.

76) S.G. Wang, C.B. Shen, K. Long, T. Zhang, F.H. Wang and Z.D. Zhang: J. Phys. Chem. B 110 (2006) 377-382.

77) B.N. Mordyuk, G.I. Prokopenko, M.A. Vasylyev and M.O. Iefimov: Mater. Sci. Eng. A 458 (2007) 253-261.

78) X.Y. Wang and D.Y. Li: Wear 255 (2003) 836-845.

79) B.N. Mordyuk, O.P. Karasevskaya and G.I. Prokopenko: Mater. Sci. Eng. A 559 (2013) 453-461.

80) B.N. Mordyuk, O.P. Karasevskaya, G.I. Prokopenko and N.I. Khripta: Surf. Coat. Tech. 210 (2012) 54-61.

81) G.-L. Song and Z. Xu: Electrochim. Acta 55 (2010) 4148-4161.

82) Z. Pu, S. Yang, G.L. Song, O.W. Dillon, Jr., D.A. Puleo and I.S. Jawahir: Scr. Mater. 65 (2011) 520-523.

$83)$ Z. Pu, G.L. Song, S. Yang, J.C. Outeiro, O.W. Dillon, Jr., D.A. Puleo and I.S. Jawahir: Corros. Sci. 57 (2012) 192-201.

84) A. Turnbull, K. Mingard, J.D. Lord, B. Roebuck, D.R. Tice, K.J. Mottershead, N.D. Fairweather and A.K. Bradbury: Corros. Sci. 53 (2011) 3398-3415.

85) G. Argade, W. Yuan, K. Kandasamy and R. Mishra: J. Mater. Sci. 47 (2012) 6812-6822

86) G.R. Argade, N. Kumar and R.S. Mishra: Mater. Sci. Eng. A 565 (2013) 80-89.

87) E. Akiyama, Z. Zhang, Y. Watanabe and K. Tsuzaki: J. Solid State Electrochem. 13 (2009) 277-282.

88) M.-K. Chung, Y.-S. Choi, J.-G. Kim, Y.-M. Kim and J.-C. Lee: Mater. Sci. Eng. A 366 (2004) 282-291.

89) I. Son, H. Nakano, S. Oue, S. Kobayashi, H. Fukushima and Z. Horita: Int. J. Corros. 2012 (2012) 1-9.

90) E.S.M. Sherif, E.A. El-Danaf, M.S. Soliman and A.A. Almajid: Int. J. Electrochem. Sci. 7 (2012) 2846-2859.

91) E.S.M. Sherif, M.S. Soliman, E.A. El-Danaf and A.A. Almajid: Int. J. Electrochem. Sci. 8 (2013) 1103-1116.

92) I.J. Son, H. Nakano, S. Oue, S. Kobayashi, H. Fukushima and Z. Horita: Trans. JIM 47 (2006) 1163-1169.

93) M. Eizadjou, H. Fattahi, A.K. Talachi, H.D. Manesh, K. Janghorban and M.H. Shariat: Corr. Eng. Sci. Tech 47 (2012) 19-24.

94) G. Meng, L. Wei, T. Zhang, Y. Shao, F. Wang, C. Dong and X. Li: Corros. Sci. 51 (2009) 2151-2157.

95) W. Deng, P. Lin, Q. Li and G. Mo: Corros. Sci. 74 (2013) 44-49.

96) R.J. Hellmig, M. Janeček, B. Hadzima, O.V. Gendelman, M. Shapiro, X. Molodova, A. Springer and Y. Estrin: Trans. JIM 49 (2008) 31-37.

97) Y. Jang, S. Kim, S. Han, C. Lim and C. Kim: J. Mater. Sci. 41 (2006) 4293-4297.

98) H. Miyamoto, K. Harada, T. Mimaki, A. Vinogradov and S. Hashimoto: Corros. Sci. 50 (2008) 1215-1220. 
99) H. Miyamoto, T. Mimaki, A. Vinogradov and S. Hashimoto: Mater. Sci. Forum 561-565 (2007) 2385-2388.

100) H. Miyamoto, T. Kishi, T. Mimaki, A. Vinogradov and S. Hashimoto. in Ultrafine Grained Materials, IV. (eds Y. T. Zhu et al.) 337.

101) B. Hadzima, M. Janecek, R.J. Hellmig, Y. Kutnyakova and Y. Estrin: Mater. Sci. Forum 503-504 (2006) 883-888.

102) A. Vinogradov, H. Miyamoto, T. Mimaki and S. Hashimoto: Ann. Chim. Sci. Mat. 27 (2002) 65-75.

103) T. Yamasaki, H. Miyamoto, T. Mimaki, A. Vinogradov and S. Hashimoto: Mater. Sci. Eng. A 318 (2001) 122-128.

104) A. Vinogradov, T. Mimaki, S. Hashimoto and R.Z. Valiev: Scr. Mater. 41 (1999) 319-326.

105) A. Fattah-alhosseini and O. Imantalab: J. Alloy. Compd. 632 (2015) $48-52$.

106) S. Tao and D.Y. Li: Nanotechnology 17 (2006) 65-78.

107) L. Zhang, A. Ma, J. Jiang, D. Yang, D. Song and J. Chen: Corros. Sci 75 (2013) 434-442.

108) A. Balyanov, J. Kutnyakova, N.A. Amirkhanova, V. Stolyarov, R.Z. Valiev, X.Z. Liao, Y.H. Zhao, Y.B. Jiang, H.F. Xu, T.C. Lowe and Y.T. Zhu: Scr. Mater. 51 (2004) 225-229.

109) N.P. Gurao, G. Manivasagam, P. Govindaraj, R. Asokamani and S. Suwas: Metall. Mater. Trans., A Phys. Metall. Mater. Sci. 44 (2013) 5602 5610.

110) M. Hoseini, A. Shahryari, S. Omanovic and J.A. Szpunar: Corros. Sci. 51 (2009) 3064-3067.

111) H. Garbacz, M. Pisarek and K.J. Kurzydłowski: Biomol. Eng. 24 (2007) 559-563.

112) M. Nie, C.T. Wang, M. Qu, N. Gao, J.A. Wharton and T.G. Langdon: J. Mater. Sci. 49 (2014) 2824-2831.

113) H.S. Kim and W.J. Kim: Corros. Sci. 89 (2014) 331-337.

114) H.S. Kim, S.J. Yoo, J.W. Ahn, D.H. Kim and W.J. Kim: Mater. Sci. Eng. A 528 (2011) 8479-8485.

115) N. Birbilis, K.D. Ralston, S. Virtanen, H.L. Fraser and C.H.J. Davis: Corr. Eng. Sci. Tech. 45 (2010) 224-230.

116) D. Song, A. Ma, J. Jiang, P. Lin, D. Yang and J. Fan: Corros. Sci. 52 (2010) 481-490.

117) Z. Li, N. Huang, J. Zhao and S.J. Zhou: Mater. Sci. Technol. 29 (2013) 140-147.

118) H. Hasegawa, S. Komura, A. Utsunomiya, Z. Horita, M. Furukawa, M. Nemoto and T.G. Langdon: Mater. Sci. Eng. A 265 (1999) 188-196.

119) U. Erb. in Uhlig's corrosion handbook 517-528 (Wiley, 2011).

120) H. Nakano, H. Yamaguchi, Y. Yamada, S. Oue, I.J. Son, Z. Horita and H. Koga: Trans. JIM 54 (2013) 1642-1649.

121) D. Song, A.B. Ma, J.H. Jiang, P.H. Lin and L.Y. Zhang: Prog. Nat. Sci. Mater. Int. 21 (2011) 307-313.

122) P. Minárik, R. Kral and B. Hadzima: Acta Physiol. Pol. 122 (2012) 614

123) F. Zhang, A. Ma, J. Jiang, H. Xu, D. Song, F. Lu and Y. Nishida: Prog. Nat. Sci. Mater. Int. 23 (2013) 420-424.

124) Z.J. Zheng, Y. Gao, Y. Gui and M. Zhu: Corros. Sci. 54 (2012) 60-67.

125) S.H. Kim, K.T. Aust, U. Erb, F. Gonzalez and G. Palumbo: Scr. Mater 48 (2003) 1379-1384.

126) R. Gupta, R.K. Singh Raman and C.C. Koch: J. Mater. Sci. 47 (2012) 6118-6124.

127) M. Pisarek, P. Kedzierzawski, M. Janik-Czachor and K.J. Kurzydlowski: Corrosion 64 (2008) 131-137.

128) R. Gupta, R.K. Singh Raman and C. Koch: J. Mater. Sci. 45 (2010) 4884-4888.

129) R.K.S. Raman, R.K. Gupta and C.C. Koch: Philos. Mag. 90 (2010) $3233-3260$.

130) R.K. Gupta, R.K. Singh Raman, C.C. Koch and B.S. Murty: Int. J. Electrochem. Sci. 8 (2013) 6791-6806.

131) C. Pan, L. Liu, Y. Li, B. Zhang and F. Wang: J. Electrochem. Soc. 159 (2012) C453-C460.

132) K. Sieradzki and R.C. Newman: J. Electrochem. Soc. 133 (1986) 19791980

133) S. Qian, R.C. Newman and R.A. Cottis: J. Electrochem. Soc. 137 (1990) 435-439.

134) M. Furukawa, P.B. Berbon, Z. Horita, M. Nemoto, N.K. Tsenev, R.Z. Valiev and T.G. Langdon: Metall. Mater. Trans., A Phys. Metall. Mater Sci. 29 (1998) 169-177.

135) A. Deschamps, F. De Geuser, Z. Horita, S. Lee and G. Renou: Acta Mater. 66 (2014) 105-117.
136) W.J. Kim, J.K. Kim, H.K. Kim, J.W. Park and Y.H. Jeong: J. Alloy. Compd. 450 (2008) 222-228.

137) S. Hirosawa, T. Hamaoka, Z. Horita, S. Lee, K. Matsuda and D. Terada: Metall. Mater. Trans., A Phys. Metall. Mater. Sci. 44 (2013) 39213933.

138) M.H. Farshidi, M. Kazeminezhad and H. Miyamoto: Mater. Sci. Eng. A 580 (2013) 202-208.

139) K. Liu, W. Du, Q. Wang, Z. Wang, S. Li and Z. Fu: Mater. Sci. Eng. A 556 (2012) 567-572.

140) J. Č́̌žek, I. Procházka, B. Smola, I. Stulíková, M. Vlach, V. Očenášek, O.B. Kulyasova and R.K. Islamgaliev: Int. J. Mater. Res. 100 (2009) 780-784.

141) G. Purcek, H. Yanar, M. Demirtas, Y. Alemdag, D.V. Shangina and S.V. Dobatkin: Mater. Sci. Eng. A 649 (2016) 114-122.

142) M. Lewandowska and K. Kurzydlowski: J. Mater. Sci. 45 (2010) 4877 4883.

143) M. Hockauf, L.W. Meyer, D. Nickel, G. Alisch, T. Lampke, B. Wielage and L. Kruger: J. Mater. Sci. 43 (2008) 7409-7417.

144) Y.H. Zhao, X.Z. Liao, S. Cheng, E. Ma and Y.T. Zhu: Adv. Mater. 18 (2006) 2280-2283.

145) H.J. Roven, M. Liu and J.C. Werenskiold: Mater. Sci. Eng. A 483-484 (2008) 54-58.

146) E. Cerri and P. Leo: Mater. Sci. Eng. A 410-411 (2005) 226-229.

147) J. Gubicza, I. Schiller, N.Q. Chinh, J. Illy, Z. Horita and T.G. Langdon: Mater. Sci. Eng. A 460-461 (2007) 77-85.

148) G. Sha, Y.B. Wang, X.Z. Liao, Z.C. Duan, S.P. Ringer and T.G. Langdon: Mater. Sci. Eng. A 527 (2010) 4742-4749.

149) G. Sha, Y.B. Wang, X.Z. Liao, Z.C. Duan, S.P. Ringer and T.G. Langdon: Acta Mater. 57 (2009) 3123-3132.

150) J.G. Brunner, N. Birbilis, K.D. Ralston and S. Virtanen: Corros. Sci. 57 (2012) 209-214.

151) J.H. Jiang, A.B. Ma, F.M. Lu, N. Saito, A. Watazu, D. Song, P. Zhang and Y. Nishida: Mater. Corr. 62 (2011) 848-852

152) I.-J. Son, H. Nakano, S. Oue, S. Kobayashi, H. Fukushima and Z. Horita: Trans. Nonferr. Met. Soc. Chn 19 (2009) 904-908.

153) J. Jiang, A. Ma, D. Song, D. Yang, J. Shi, K. Wang, L. Zhang and C.H. Chen: J. Mater. Sci. 47 (2012) 7744-7750.

154) D. Song, A.B. Ma, J.H. Jiang, P.H. Lin, D.H. Yang and J.F. Fan: Corros. Sci. 53 (2011) 362-373.

155) K.S. Suresh, M. Geetha, C. Richard, J. Landoulsi, H. Ramasawmy, S. Suwas and R. Asokamani: Mater. Sci. Eng. C 32 (2012) 763-771.

156) W. Wei, K.X. Wei and Q.B. Du: Mater. Sci. Eng. A 454-455 (2007) 536-541.

157) D. Orlov, K.D. Ralston, N. Birbilis and Y. Estrin: Acta Mater. 59 (2011) 6176-6186.

158) Z. Zhang, E. Akiyama, Y. Watanabe, Y. Katada and K. Tsuzaki: Corros. Sci. 49 (2007) 2962-2972.

159) O. Jilani, N. Njah and P. Ponthiaux: Corros. Sci. 87 (2014) 259-264.

160) M.F. Naeini, M.H. Shariat and M. Eizadjou: J. Alloy. Compd. 509 (2011) 4696-4700

161) J.G. Brunner, J. May, H.W. Höppel, M. Göken and S. Virtanen: Electrochim. Acta 55 (2010) 1966-1970.

162) A. Korchef and A. Kahoul: Int. J. Corros. 2013 (2013) 983261 1-11.

163) E. Kus, Z. Lee, S. Nutt and F. Mansfeld: Corrosion 62 (2006).

164) H. Nakano, S. Oue, S. Taguchi, S. Kobayashi and Z. Horita: Int. J. Corros. 2012 (2012) 1-8

165) Ł. Dolega, B. Adamczyk-Cieślak, J. Mizera and K.J. Kurzydłowski: J. Mater. Sci. 47 (2012) 3026-3033.

166) K.S. Ghosh, N. Gao and M.J. Starink: Mater. Sci. Eng. A 552 (2012) 164-171.

167) I.J. Son, H. Nakano, S. Oue, S. Kobayashi, H. Fukushima and Z. Horita: Trans. JIM 48 (2007) 21-28.

168) I.J. Son, H. Nakano, S. Oue, S. Kobayashi, H. Fukushima and Z. Horita: Trans. JIM 49 (2008) 2648-2655.

169) I.J. Son, H. Nakano, S. Oue, S. Kobayashi, H. Fukushima and Z. Horita: Trans. JIM 49 (2008) 2656-2663.

170) A. Yulinova, D. Nickel, P. Frint and T. Lampke: Mater. Sci. 48 (2012) 191-196.

171) D. Song, A.B. Ma, J.H. Jiang, P.H. Lin and J. Shi: Corr. Eng. Sci. Tech. 46 (2011) 505-512.

172) J.H. Gao, S.K. Guan, Z.W. Ren, Y.F. Sun, S.J. Zhu and B. Wang: Mater Lett. 65 (2011) 691-693. 
173) J. Jiang, A. Ma, N. Saito, Z. Shen, D. Song, F. Lu, Y. Nishida, D. Yang and P. Lin: J. Rare Earths 27 (2009) 848-852.

174) P. Minárik, R. Král and M. Janeček: Appl. Surf. Sci. 281 (2013) 44-48.

175) J. Vrátná, B. Hadzima, M. Bukovina and M. Janeček: J. Mater. Sci. 48 (2013) 4510-4516.

176) G.B. Hamu, D. Eliezer and L. Wagner: J. Alloy. Compd. 468 (2009) 222-229.

177) X.N. Gu, N. Li, Y.F. Zheng, F. Kang, J.T. Wang and L. Ruan: Mater. Sci. Eng. B 176 (2011) 1802-1806.

178) H. Wang, Y. Estrin and Z. Zúberová: Mater. Lett. 62 (2008) 2476-2479.

179) B. Hadzima, M. Janecek, M. Bukovina and R. Kral: Int. J. Corros. 100 (2009) 1213-1216.

180) A. Barbucci, G. Farne, P. Matteazzi and R. Riccieri: Corros. Sci. 41 (1998) 463-475.

181) M. Rifai, H. Miyamoto and H. Fujiwara: Int. J. Corros. 2015 (2015) 386865 1-9.

182) G. Chen, Y. Gao, S. Wu and J. Hu: Adv. Mater. Res. 194-196- (2011) 411-415.

$183)$ B. Hadzima, M. Janeček, Y. Estrin and H.S. Kim: Mater. Sci. Eng. A 462 (2007) 243-247.

184) A.T. Krawczynska, M. Gloc and K. Lublinska: J. Mater. Sci. 48 (2013) 4517-4523.

185) M. Pisarek, P. Kędzierzawski, M. Janik-Czachor and K.J. Kurzydłowski: J. Solid State Electrochem. 13 (2009) 283-291.

186) D. Raducanu, E. Vasilescu, V.D. Cojocaru, I. Cinca, P. Drob, C. Vasilescu and S.I. Drob: J. Mech. Behav. Biomed. Mater. 4 (2011) 1421-1430.

187) R. Figueiredo and T. Langdon: J. Mater. Sci. 45 (2010) 4827-4836.

188) J. Xing, X. Yang, H. Miura and T. Sakai: Trans. JIM 49 (2008) 69-75.

189) L. Lu, T. Liu, J. Chen and Z. Wang: Mater. Des. 36 (2012) 687-693.

190) C. Blawert, D. Manova, M. Störmer, J.W. Gerlach, W. Dietzel and S. Mändl: Surf. Coat. Tech. 202 (2008) 2236-2240.

191) R. Xin, B. Li, L. Li and Q. Liu: Mater. Des. 32 (2011) 4548-4552.

192) R. Xin, Y. Luo, A. Zuo, J. Gao and Q. Liu: Mater. Lett. 72 (2012) 1-4.

193) G.-L. Song: J. o. M. 64 (2012) 671-679.

194) E. Mostaed, M. Hashempour, A. Fabrizi, D. Dellasega, M. Bestetti, F. Bonollo and M. Vedani: J. Mech. Behav. Biomed. Mater. 37 (2014) 307-322.
195) G.-L. Song, R. Mishra and Z. Xu: Electrochem. Commun. 12 (2010) 1009-1012.

196) M. Liu, D. Qiu, M.-C. Zhao, G. Song and A. Atrens: Scr. Mater. 58 (2008) 421-424.

197) G.-L. Song and Z. Xu: Corros. Sci. 63 (2012) 100-112.

198) G.-L. Song and Z. Xu: Corros. Sci. 54 (2012) 97-105.

199) F.W. Young: J. Appl. Phys. 32 (1961) 192-201.

200) L.C. Lovell and J.H. Wernick: J. Appl. Phys. 30 (1959) 590-592.

201) J.D. Livingston: J. Appl. Phys. 31 (1960) 1071-1076.

202) H.S. Kim and W.J. Kim: Corros. Sci. 75 (2013) 228-238.

203) V.Y. Gertsman, R. Birringer and R.Z. Valiev: Pys. Stat. Sol. 149 (1995) 243-252 (a).

204) V.Y. Gertsman, R. Birringer, R.Z. Valiev and H. Gleiter: Scr. Metall. Mater. 30 (1994) 229-234.

205) R.K. Islamgaliev, F. Chmelik and R. Kuzel: Mater. Sci. Eng. A 237 (1997) 43-51.

206) J. Wang, M. Furukawa, Z. Horita, M. Nemoto, R.Z. Valiev and T.G. Langdon: Mater. Sci. Eng. A 216 (1996) 41-46.

207) H.G. Jiang, Y.T. Zhu, D.P. Butt, I.V. Alexandrov and T.C. Lowe: Mater. Sci. Eng. A 290 (2000) 128-138.

208) R.Z. Valiev, A.V. Korznikov and R.R. Mulyukov: Mater. Sci. Eng. A 168 (1993) 141-148.

209) A.A. Nazarov: Int. Sci. 8 (2000) 71-76.

210) A.A. Nazarov: Phys. Solid State 45 (2003) 1166-1169.

211) S.J. Splinter, R. Rofagha, N.S. McIntyre and U. Erb: Surf. Interface Anal. 24 (1996) 181-186.

212) K.J. Kurzydłowski, W. Zielinski and J. Wyrzykowski: Mater. Sci. Technol. 2 (1986) 420-421.

213) W.A. Światnicki, W. Łojkowski and M.W. Grabski: Acta Metall. 34 (1986) 599-605.

214) W.A. Swiatnicki, S. Poulat, L. Priester, B. Decamps and M.W. Grabski: Acta Mater. 46 (1998) 1711-1717.

215) S.-X. Li, Y.-N. He, S.-R. Yu and P.-Y. Zhang: Corros. Sci. 66 (2013) 211-216.

216) H. Miyamoto, A. Vinogradov and S. Hashimoto: Mater. Sci. Forum 584-586 (2008) 887-892. 